\title{
Artichoke Extract as an Eco-Friendly Corrosion Inhibitor for Zinc in 1 M Hydrochloric Acid Solution
}

\author{
Hanaa M. Elabbasy ${ }^{1, *}$, Omnia A. Mohamed ${ }^{2}$, Abd El-Aziz S. Fouda ${ }^{2}$ \\ 1 Misr Higher Institute for Engineering and Technology, Mansoura, Egypt; helabbasy@ hotmail.com (H.M.E.); \\ 2 Department Chemistry, Faculty of Science, Mansoura University, Mansoura-35516, Egypt; asfouda@ hotmail.com (A.E- \\ A.S.F.); \\ * Correspondence: helabbasy @hotmail.com (H.M.E.);
}

Scopus Author ID 57194688431

Received: 17.01.2021; Revised: 30.03.2021; Accepted: 10.04.2021; Published: 7.05.2021

\begin{abstract}
Artichoke extract (AE) was studied as the corrosion inhibitor for zinc in $1 \mathrm{M} \mathrm{HCl}$ utilizing chemical and electrochemical methods. The adsorption isotherm of Artichoke extract on $\mathrm{Zn}$ surface accords with Langmuir adsorption isotherm. The inhibition efficiency increases with increasing the extract's concentration and decreases with the rise in the medium's temperature. The inhibition efficiency reached a value of $93.2 \%$ at $300 \mathrm{ppm}$ of extract. This extract may be forming a film and acts as a barrier, which minimizes the contact area between zinc surface and $\mathrm{HCl}$ solution. Artichoke extract acts as a mixed inhibitor in $\mathrm{HCl}$ solution. Thermodynamic parameters of activation and adsorption were determined and explained. The adsorption parameters also obeyed the Langmuir adsorption isotherm, and the sign of the free energy of adsorption showed a spontaneous process. The surface morphology of zinc metal was examined by employing various techniques. Also, the biological effect of the Artichoke extract was studied. Theoretical studies of quantum mechanics and molecular dynamics simulations studies were carried out on the Artichoke extract compounds, and the results agree with the experimental one. The efficiencies marked from all employed techniques were in perfect correspondence, demonstrating the validity of these procedures.
\end{abstract}

Keywords: zinc; artichoke extract; corrosion inhibition; HCl; AFM; biological effect; SEM.

(C) 2021 by the authors. This article is an open-access article distributed under the terms and conditions of the Creative Commons Attribution (CC BY) license (https://creativecommons.org/licenses/by/4.0/).

\section{Introduction}

$\mathrm{Zn}$ is a non-ferrous metal used in metallic coating, extensively, a natural metal founds in the earth's crust. Besides rock and soil, present in water, air, and the biosphere, is concluded in plants, animals, and humans. Zinc is a metal with numerous industrial applications and is mainly used for the corrosion protection of steel [1]. Zinc is an industrially important metal and is corroded by many agents, of which aqueous acids are the most dangerous [2]. Zn metal is highly susceptible to attack by acids, especially sulphuric and hydrochloric acids. In the current industry, acids are used for the chemical cleaning of metals and alloys. Thence for scale elimination and cleaning of zinc surfaces by acidic solutions, it is required to use inhibitors [3]. The employment of the plant extracts as inhibitors to lower the dissolution of metals in several typical industrial solutions was performed by several authors [4-18]. Inhibitors from plant extracts are characterized by their renewable resources, facilely obtainable, low cost, and no harmful effects on the environment [19]. The green corrosion extracts mainly contain the needful elements (such as $\mathrm{O}, \mathrm{C}, \mathrm{N}$, and $\mathrm{S}$ ) that help molecules to be adsorbed on the surfaces of metals or alloys to form a film that protects the surface from corroded [20]. There is no 
indication to apply this extract as a corrosion inhibitor for zinc in $\mathrm{HCl}$ solution in the literature survey. This encourages us to utilize this extract as a corrosion inhibitor for zinc in $\mathrm{HCl}$ medium. Artichoke extract AE (Cynara cardunculus var. scolymus) [21], Family: Asteraceae [22]. It is an accepted known plant, coming from the Mediterranean Sea, Italy, and Spain. Artichoke consists of apigenin and luteolin bioactive agents [23]. Its leaves are consumed as vegetables worldwide and are applied, for a long time, in herbal medication as a choleretic [24]. Besides polyphenols and flavonoids, some mono- and dicaffeoylquinic acids were found as the main portion in the chemical constituents of artichoke leaves [25].

This research article evaluates the $\mathrm{AE}$ as an inhibitor for $\mathrm{Zn}$ in a corrosive acid medium by employing several techniques. This included the elucidation of the protection mechanism involved.

\section{Materials and Methods}

\subsection{Materials and plant preparations.}

The acid corrosive medium $(1 \mathrm{M} \mathrm{HCl})$ was prepared by diluting a reagent of analytical grade $\mathrm{HCl} 37 \%$ with bi-distilled water. The composition of the applied $\mathrm{Zn}$ as weight $\%$ is $\mathrm{Cd}$ (0.52), $\mathrm{Fe}(0.035), \mathrm{Mn}(0.005), \mathrm{Pb}(0.18), \mathrm{Sn}(0.07)$, and $\mathrm{Zn}$ rest. The $\mathrm{Zn}$ sheet of thickness 0.1 $\mathrm{cm}$ was mechanically press-cut into $2 \times 2 \mathrm{~cm}$ coupons for ML measurements and $1 \times 1 \mathrm{~cm}$ for electrochemical measurements. The samples were abraded with varying degrees of emery papers reaching 2000 grades, cleaned and washed using acetone and bi-distilled water, and dry with filter paper. The coupons were then ready to use in the corrosion studies. The freshly Artichoke parts were firstly prepared to dehydrate, milled to a powder. Then, $500 \mathrm{~g}$ of the powder drenched in methanol, boiling at $100{ }^{\circ} \mathrm{C}$, and preserved at room temperature for about 72 hours. After that, the AE is filtrated and put in the air to dry. To attain 1000 ppm stock solution of the extract, one-gram from the dried AE is dissolved in one litter bi-distilled water. Various concentrations (from 50 to $300 \mathrm{ppm}$ ) are prepared from the AE solution through dilution with bi-distilled water.

\subsection{Mass loss (ML) method.}

Zn samples with dimensions $2 \times 2 \times 0.1 \mathrm{~cm}$ were utilized in this method. Before all experiments, the samples were mechanically abraded by $800-2000$ grades of emery papers, washed by bi-distilled water, degreased with acetone, dried by filter paper, and weighed accurately by employing an analytical balance by $0.1 \mathrm{mg}$ of precision. The samples then suspended in solutions of $100 \mathrm{ml}$ of the corrosive acid medium without and with $(50,100,150$, 200, 250, and $300 \mathrm{ppm})$ of AE for different immersion time (60, 120, 180, 240, 300, and 360 $\mathrm{min}$ ), then the samples were taken away and handled following the process cleared in ASTM term G1-90 [26].

\subsection{Electrochemical techniques.}

For electrochemical procedures, a conventional glass cell of three electrodes was employed. A cylindrical rod working electrode ( $\mathrm{Zn}$ metal) was placed into a glass tube of

appropriate diameter using epoxy resin. It offered an active flat-disc-shaped surface of $1 \mathrm{~cm}^{2}$ geometric area to contact with the electrolyte, saturated calomel electrode (SCE) as a reference electrode, and auxiliary electrode (Pt), respectively [27]. Before each electrochemical 
measurement, the $\mathrm{Zn}$ electrode was polished with emery papers and treated as in ML, left for $30 \mathrm{~min}$ in the solution to give a chance to the open circuit potential to attain a steady-state [28]. The potentiodynamic polarization (PP) curves were recorded in the potential range of -500 to $+500 \mathrm{mV}$ relating to the open circuit potential (Eocp) at a scan rate of $0.5 \mathrm{mV} \mathrm{s}^{-1}$.

Electrochemical impedance spectroscopy (EIS) was recorded at open circuit potential, OCP. The AC signal was $10 \mathrm{mV}$ peak to peak with a frequency range between $50 \mathrm{kHz}$ and 0.1 $\mathrm{Hz}$.

The electrochemical frequency modulation (EFM) procedures employed a potential amplitude of $10 \mathrm{mV}$, with two sine waves of 2 and $5 \mathrm{~Hz}$. The EFM procedure outcomes are spectra (termed intermodulation spectra) of current response as a function of frequency. The spectra consist of current responses selected for harmonically and intermodulation current peaks. The bigger peaks were employed to attain the corrosion current density (icorr), the causality factors (CF-2 and CF-3), and the Tafel slopes ( $\beta \mathrm{c}$ and $\beta a)$ [29]. The large strength of the EFM is the causality factors that show an internal check on the sincerity of the EFM procedure [30]. For the reproduction of the data, each experiment was repeated at least three times.

Electrochemical techniques were carried out using Potentiostat/ Galvanostat (Gamry PCI 300/4) with software DC105 for polarization, EIS300 for EIS, and EFM140 for EFM, connected to a computer for data record and store. All the experiments were carried out at 25 ${ }^{\circ} \mathrm{C}$ using an ultra circulating thermostat, and solutions were not deaerated. Each experiment was performed on a newly abraded electrode using a freshly prepared electrolyte.

\subsection{Surface analysis.}

2.4.1. Scanning electron microscopy (SEM) and energy dispersion X-ray (EDX) analysis.

SEM and EDX analysis of Zn surface before and after immersion for 24 hours in the corrosive acid medium without and with $300 \mathrm{ppm}$ (the higher concentration) of AE were studied using apparatus model: JEOL (Japan JSM IT - 100).

\subsubsection{Atomic force microscopy (AFM) analysis.}

AFM is an effective method for examining $\mathrm{Zn}$ metal's surface morphology at a nano- to micro- scale. The essential feature of this test is that the roughness of the surface can be recorded. AFM tests were carried out using prepared $\mathrm{Zn}$ specimens before and after immersion for 24 hours in the corrosive acid medium without and with 300 ppm of AE.

\subsubsection{Fourier-transform infrared spectroscopy (FT-IR) studies.}

FT-IR spectra were registered in a spectral range 4000 to $500 \mathrm{~cm}^{-1}$ with the technique of Attenuated Total Reflectance (ATR) using FTIR-Spectrometer iS 10 (Thermo Fisher Scientific, USA). FT-IR spectrum is an effective way to compare between the inhibitor and corrosion products after inhibitor adsorption. The FT-IR peak values were recorded for AE and for $\mathrm{Zn}$ after immersion for 24 hours in the corrosive acid medium containing $300 \mathrm{ppm}$ of AE.

\subsubsection{Ultraviolet-visible spectroscopic (UV) test.}

The formation of a metal complex is supported mainly by using the Ultraviolet-visible spectroscopic test. The UV absorption spectra of the corrosive acid medium with $300 \mathrm{ppm}$ of 
$\mathrm{AE}$ were investigated without and after $\mathrm{Zn}$ immersion for 24 hours. The UV spectra were carried out using UV spectrometer T80+ (UV TIS model, UK).

\subsection{Biological effect.}

A biological effect test was carried out for $\mathrm{AE}$ to detect multiplying bacteria by determining the number of Bacteria colonies using the Doc-it colony counter instrument.

\section{Results and Discussion}

\subsection{Mass loss (ML) test.}

The effect of adding different concentrations (from 50 to $300 \mathrm{ppm}$ ) of $\mathrm{AE}$ to $\mathrm{Zn}$ 's corrosive solution was tested using ML. The average ML at a definite time for the $\mathrm{Zn}$ samples was taken as follows:

$$
\Delta \mathrm{W}=\mathrm{W}_{\mathbf{o}^{-}}-\mathrm{W}_{1}
$$

where $\mathrm{W}_{\mathbf{o}}$ and $\mathrm{W}_{1}$ are the weights of the $\mathrm{Zn}$ samples before and after immersion in the acid corrosive medium, respectively. The inhibition efficiency (\% IE) of $\mathrm{AE}$ and $\mathrm{Zn}$ surface coverage $(\Theta)$ can be determined as follows:

$$
\% \mathrm{IE}=\Theta \times 100=\left[1-\left(\Delta \mathrm{W}_{\text {inh }} / \Delta \mathrm{W}_{\text {free }}\right)\right] \times 100
$$

where $\Delta \mathrm{W}_{\text {inh }}$ and $\Delta \mathrm{W}_{\text {free }}$ are the ML (mg) without and with AE, respectively. The corrosion process rate (C.R) is calculated as follows:

$$
\text { C.R. }=\Delta \mathrm{W} / \mathrm{At}
$$

where $\mathrm{A}$ is the area of specimens in $\mathrm{cm}^{2}$ and $\mathrm{t}$ is the immersion time in min. Figure 1 illustrated the relationship between ML of different AE concentrations and time (in min) at $25^{\circ} \mathrm{C}$.

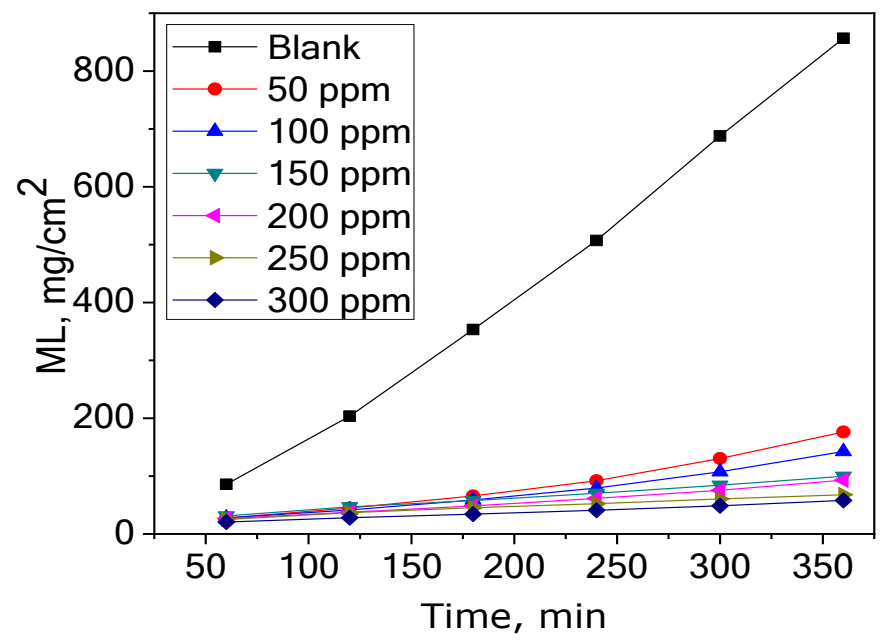

Figure 1. Effect of rising amount of $\mathrm{AE}$ on $\mathrm{ML}$ at $25^{\circ} \mathrm{C}$ for $\mathrm{Zn}$ in the corrosive acid medium.

The ML of $\mathrm{Zn}$ in the existence of AE was considerably less than that attained in the blank corrosive medium. Meaning that the adsorption of extract molecules on the $\mathrm{Zn}$ surface makes a block between the metal and the corrosive acid medium. Hence, the corrosion rate decreases and \% IE increases. This indicates that AE behaves as a corrosion inhibitor. 


\subsubsection{Effect of temperature.}

The influence of temperature on C.R. (Figure 2) and on \% IE (Figure 3) for $\mathrm{Zn}$ in the corrosive acid medium without and with different concentrations of $\mathrm{AE}$ was analyzed by $\mathrm{ML}$ tests in the temperature range (from 25 to $45^{\circ} \mathrm{C}$ ). The figures demonstrate that the increase in AE concentration decreases C.R. and increases \% IE at all the applied temperatures. This is typically due to the increase of adsorption and coverage of metal surfaces with the raising of AE [31].

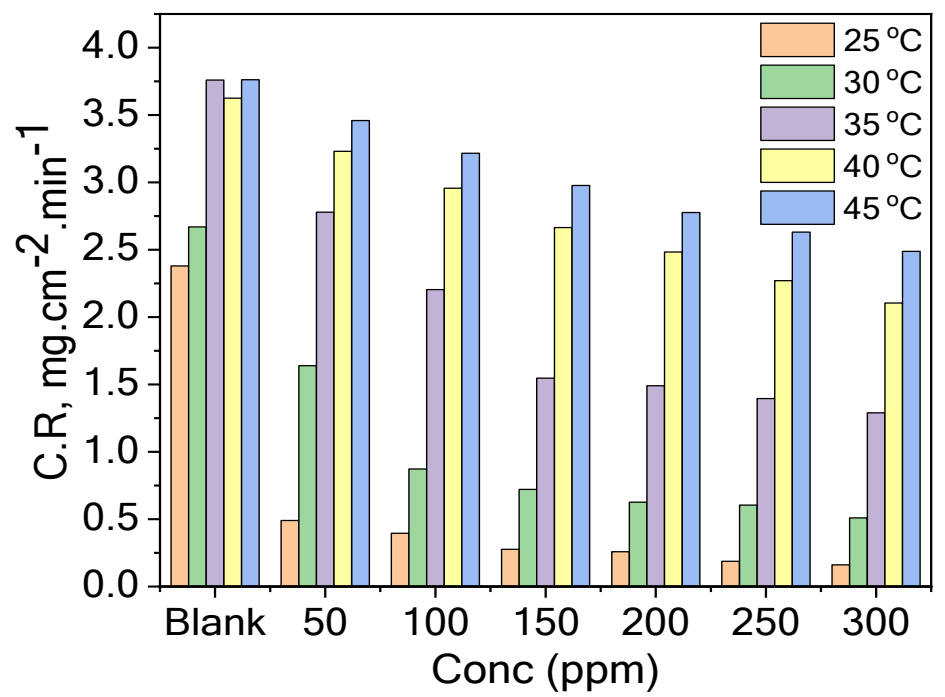

Figure 2. C.R of $\mathrm{Zn}$ in the corrosive acid medium vs. concentration of $\mathrm{AE}$ at different temperatures.

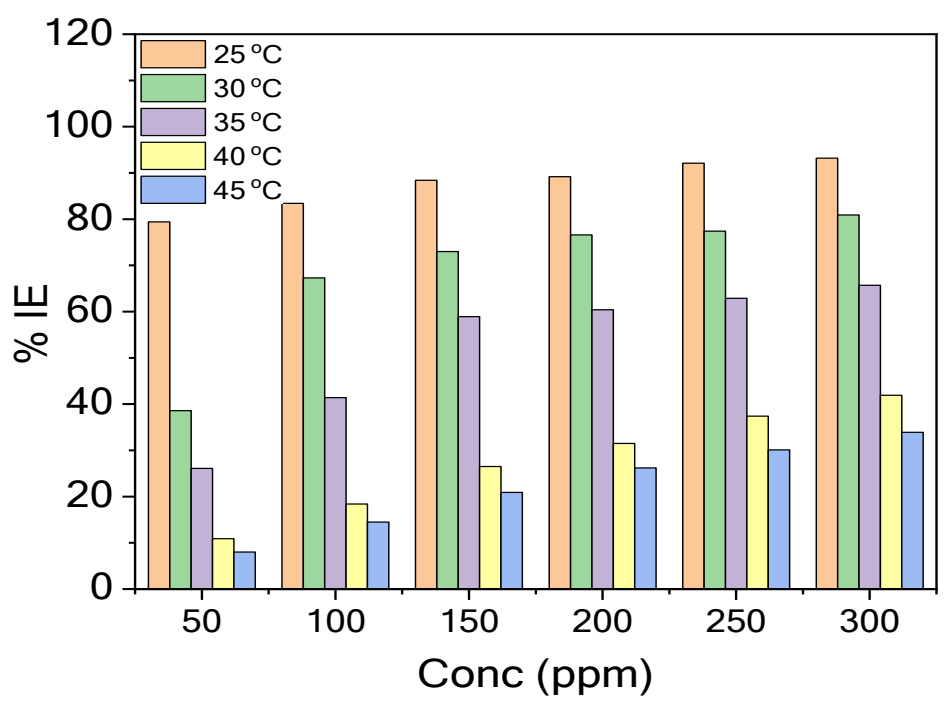

Figure 3. \% IE of different AE concentrations for $\mathrm{Zn}$ in the corrosive acid medium at different temperatures.

The estimation of activation energies $\left(\mathrm{E}_{\mathrm{a}}{ }^{*}\right)$ for corrosion of $\mathrm{Zn}$ in uninhibited and inhibited acid corrosive medium were computed by employing the following Arrhenius equation:

$\log$ C.R. $=-\mathrm{E}_{\mathrm{a}}^{*} / 2.303 \mathrm{RT}+\log \mathrm{A}$

where $\mathrm{A}$ is Arrhenius pre-exponential multiplier, $\mathrm{T}$ is Kelvin temperature, $\mathrm{R}$ is universal gas constant in joule/mol/K unit. Straight lines were obtained by plotting log C.R versus $1 / \mathrm{T}$ without and with different AE concentrations (Figure 4) with slope equals (-Ea $\left.{ }^{*} / 2.303 \mathrm{R}\right)$. The entropy $\left(\Delta \mathrm{S}^{*}\right)$ and enthalpy $\left(\Delta \mathrm{H}^{*}\right)$ of the activation process for $\mathrm{Zn}$ in the corrosive acid medium without and with different concentrations of $\mathrm{AE}$ were computed by employing the next transition-state equation: 
C.R $=$ RT/Nh $\exp ^{\left(\Delta \mathrm{S}^{*} / \mathrm{R}\right)} \exp ^{\left(-\Delta \mathrm{H}^{*} / \mathrm{RT}\right)}$

where $\mathrm{N} \& \mathrm{~h}$ represents Avogadro's number and Planck's constant, respectively. Straight lines were obtained by plotting $\log$ C.R/T versus $1 / T$ without and with different concentrations of $\mathrm{AE}$ (Figure 5) with slope equals $\left(-\Delta \mathrm{H}^{*} / 2.303 \mathrm{R}\right)$, and the intercept equals $\left[\left(\log (\mathrm{R} / \mathrm{Nh})+\left(\Delta \mathrm{S}^{*} / 2.303 \mathrm{R}\right)\right)\right]$. The computed activation parameters $\left(\mathrm{E}_{\mathrm{a}}{ }^{*}, \Delta \mathrm{H}^{*}\right.$, and $\left.\Delta \mathrm{S}^{*}\right)$ were provided in Table 1 . The data in Table 1 illustrated that the values of $\mathrm{E}_{\mathrm{a}}{ }^{*}$ in the existence of $\mathrm{AE}$ are higher than that in the blank corrosive medium.

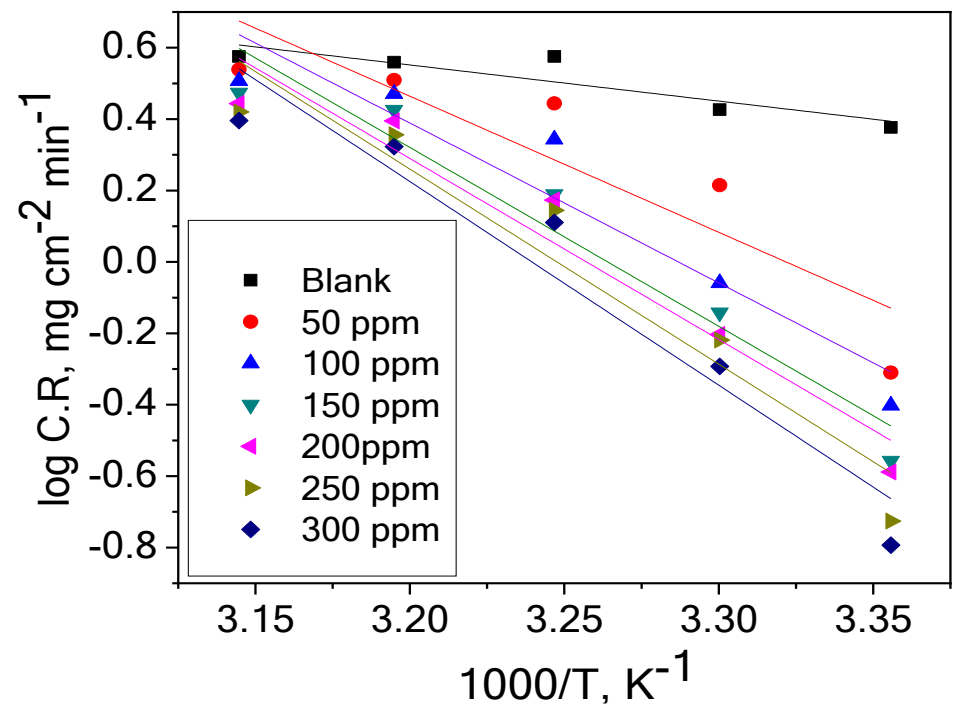

Figure 4. Plotting $\log$ C.R. against $1 / \mathrm{T}$ for $\mathrm{Zn}$ in the acid corrosive medium without and with different $\mathrm{AE}$ concentrations.

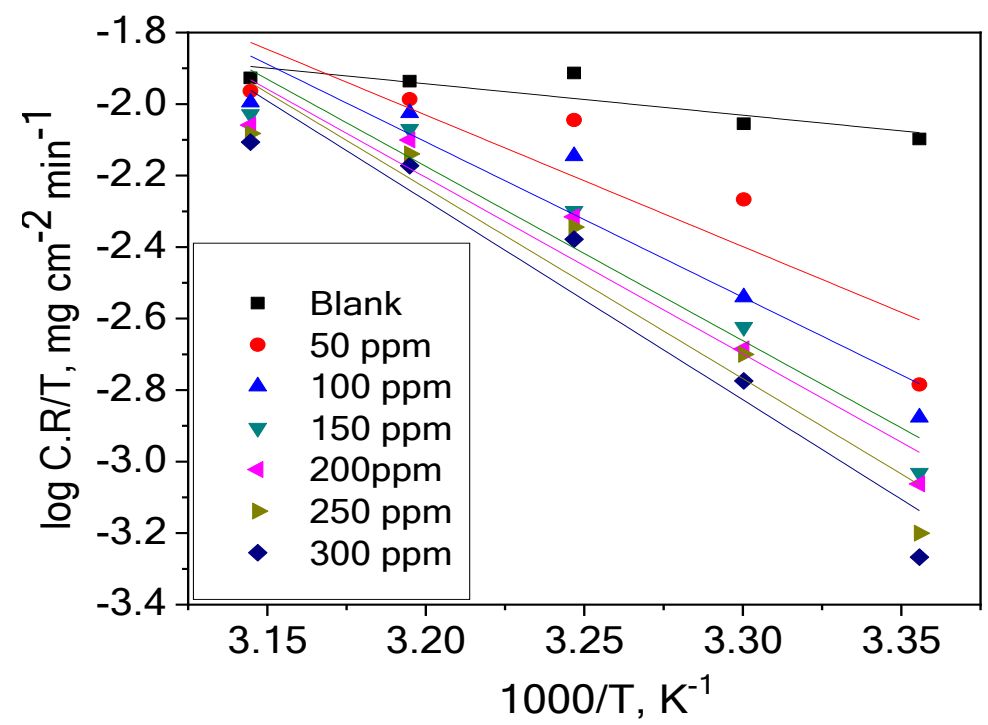

Figure 5. Plotting $\log C \cdot R / T$ against $1 / \mathrm{T}$ for $\mathrm{Zn}$ in the acid corrosive medium without and with different $\mathrm{AE}$ concentrations.

The increase in the $\mathrm{E}_{\mathrm{a}}{ }^{*}$ indicates a high adsorption of the AE particles on the $\mathrm{Zn}$ surface. As indicated from Table 1, $\Delta \mathrm{H}^{*}$ values have positive signs, which means that the AE molecules are adsorbed endothermically on the $\mathrm{Zn}$ surface. The increase in $\Delta \mathrm{H}^{*}$ in the AE's existence indicates that the energy barrier in the corrosion reaction increases. The mean difference between $\mathrm{Ea}^{*}$ and $\Delta \mathrm{H}^{*}$ is about $2.6 \mathrm{~kJ} \mathrm{~mol}^{-1}$, which is nearly the $\mathrm{RT}$ value $\left(2.63 \mathrm{~kJ} \mathrm{~mol}^{-1}\right)[32,33]$. This proves that the dissolution of $\mathrm{Zn}$ in the corrosive acid medium is a unimolecular reaction. The values of $\Delta \mathrm{S}^{*}$ in Table 1 prove that the activated complex in the rate-determining step displays an association instead of dissociation, i.e., the disorder is done on the path of transmitting from reactant to activated complex [34]. 
Table 1. Activation parameters $\left(\mathrm{E}_{\mathrm{a}}{ }^{*}, \Delta \mathrm{H}^{*}\right.$, and $\left.\Delta \mathrm{S}^{*}\right)$ for $\mathrm{Zn}$ in the corrosive acid medium without different $\mathrm{AE}$

\begin{tabular}{c|c|c|c}
\multirow{2}{*}{$\mathbf{C}_{\text {inh, } \mathbf{p p m}}$} & $\begin{array}{c}\mathbf{E}_{\mathbf{a}}{ }^{*}, \\
\mathbf{k J} / \mathbf{m o l}\end{array}$ & $\begin{array}{c}\Delta \mathbf{H}^{*}, \\
\mathbf{k J} / \mathbf{m o l}\end{array}$ & $\begin{array}{c}\Delta \mathbf{S}^{*}, \\
\mathbf{J} / \mathbf{m o l} / \mathbf{K}\end{array}$ \\
\hline Blank & 19.4 & 16.8 & -180.86 \\
\hline 50 & 73.0 & 70.4 & -11.14 \\
\hline 100 & 85.7 & 83.2 & 28.30 \\
\hline 150 & 95.9 & 93.3 & 59.51 \\
\hline 200 & 97.1 & 94.5 & 62.63 \\
\hline 250 & 104.6 & 102.0 & 86.16 \\
\hline 300 & 109.2 & 106.6 & 100.28
\end{tabular}

3.1.2. Adsorption study.

To definite the corrosion mechanism, several adsorption isotherms were employed. The obtained data agreement with Langmuir adsorption isotherm, in which the surface part covered by the inhibitor $(\theta)$ is related to the inhibitor concentration $(C)$ through the following equation:

$\mathrm{C} / \theta=1 / \mathrm{K}_{\mathrm{ads}}+\mathrm{C}$

where $\mathrm{K}_{\mathrm{ads}}$ is to the adsorption equilibrium constant. The plots of Langmuir isotherm at different temperatures were shown in Figure 6 . The values of free energy of adsorption $\left(\Delta \mathrm{G}^{\mathrm{o}}\right.$ ads $)$ were gotten as follow:

$\log \mathrm{K}_{\mathrm{ads}}=1 / 55.5 \exp \left(\Delta \mathrm{G}^{\mathrm{o}}\right.$ ads $\left./ 2.303 \mathrm{RT}\right)$

Where 55.5 is to the water concentration in $(\mathrm{mol} / \mathrm{L})$ at the solution/metal interface. The counted values of $\mathrm{K}_{\text {ads }}$ and $\Delta \mathrm{G}^{\mathrm{o}}$ ads were tabulated in Table 2 . The negative values of $\Delta \mathrm{G}^{\mathrm{o}}$ ads signalize that the adsorption process of $\mathrm{AE}$ on $\mathrm{Zn}$ surface is spontaneous [35]. The obtained lower values for $\Delta \mathrm{G}^{\mathrm{o}}$ ads, which lie among $20.4 \mathrm{~kJ} / \mathrm{mol}$ and $12.1 \mathrm{~kJ} / \mathrm{mol}$, appear that an electrostatic interaction occurs between $\mathrm{AE}$ and $\mathrm{Zn}$ surface (physisorption) [36].

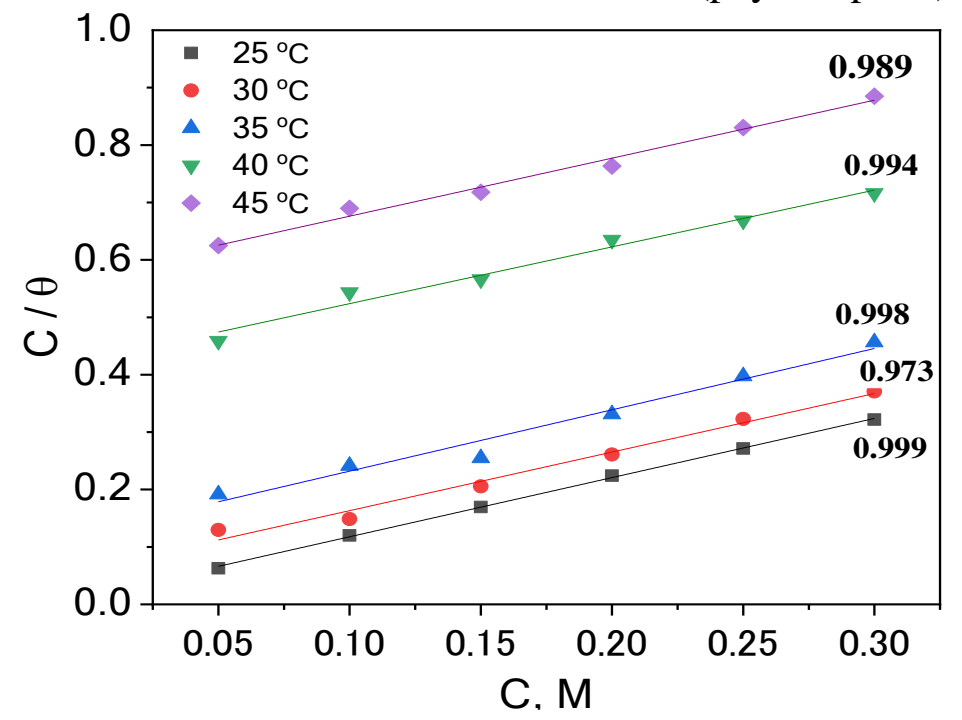

Figure 6. Plots of $\mathrm{C} / \Theta$ vs. $\mathrm{C}$ at different temperatures for $\mathrm{Zn}$ in the corrosive acid medium in the presence of AE.

The enthalpy of adsorption $\left(\Delta \mathrm{H}^{\mathrm{o}}\right.$ ads $)$ was computed utilizing the following Vant Hoff eq. [37]:

$$
\log \mathrm{K}_{\mathrm{ads}}=-\Delta \mathrm{H}^{\mathrm{o}} \text { ads } / 2.303 \mathrm{RT}+\mathrm{constant}
$$


Plotting $\log \mathrm{K}_{\mathrm{ads}}$ versus $1 / \mathrm{T}$ gives a straight line, as shown in Figure 7 . The entropy of adsorption $\left(\Delta \mathrm{S}^{\mathrm{o}}\right.$ ads $)$ can be calculated as follows:

$$
\Delta \mathrm{S}_{\text {ads }}^{\mathrm{o}}=\left(\Delta \mathrm{H}^{\mathrm{o}}{ }_{\mathrm{ads}}-\Delta \mathrm{G}^{\mathrm{o}}{ }_{\mathrm{ads}}\right) / \mathrm{T}
$$

The calculated $\Delta \mathrm{H}^{\mathrm{o}}$ ads and $\Delta \mathrm{S}_{\text {ads }}$ values are recorded in Table 2. The negative sign of $\Delta \mathrm{H}^{\mathrm{o}}$ ads points out exothermally adsorption of $\mathrm{AE}$ on $\mathrm{Zn}$ surface. The calculated values of $\Delta \mathrm{S}^{\mathrm{o}}$ ads point out that an entropy decrease accompanied the process of adsorption.

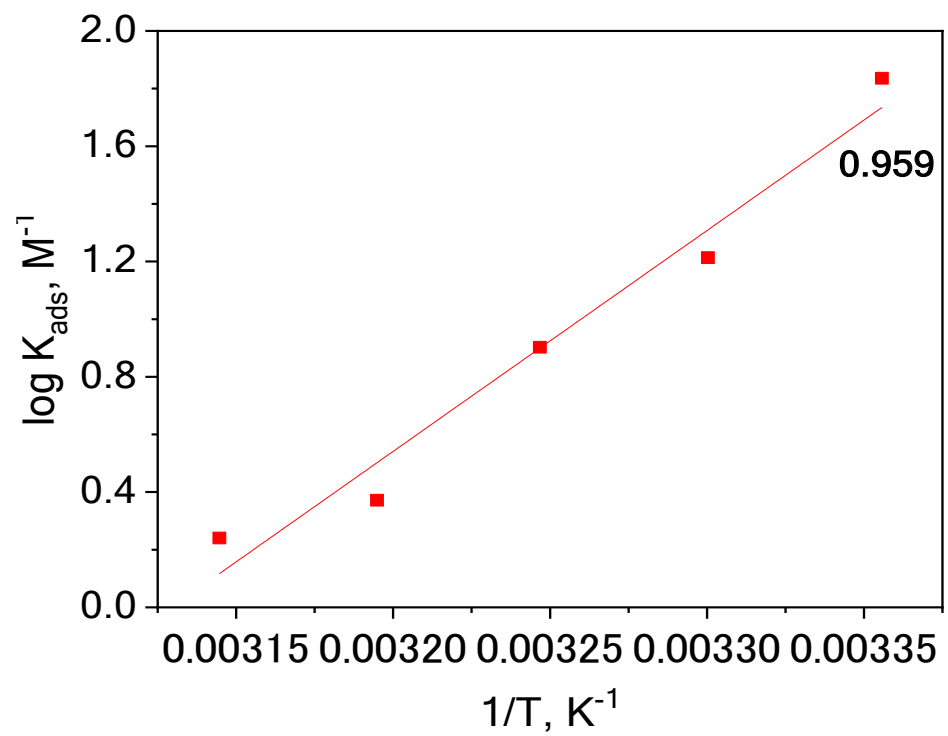

Figure 7. $\log \mathrm{K}_{\mathrm{ads}}$ vs. $1 / \mathrm{T}$ for $\mathrm{Zn}$ in the corrosive acid medium in the presence of $\mathrm{AE}$.

Table 2. Adsorption parameters for $\mathrm{Zn}$ in the corrosive acid medium in the existence of $\mathrm{AE}$ at different

\begin{tabular}{|c|c|c|c|c|c|}
\hline $\mathrm{T},{ }^{\circ} \mathrm{C}$ & Slope & $\mathbf{K}_{\text {ads, }} \mathbf{M}^{-1}$ & $\begin{array}{l}\text { temperatures. } \\
-\Delta \mathbf{G}_{\text {ads, }}^{\mathbf{a}} \mathbf{k J} / \mathbf{m o l}\end{array}$ & $-\Delta \mathbf{H}_{\text {ads }}, \mathbf{k J} / \mathbf{m o l}$ & $-\Delta \mathbf{S}_{\text {ads, }} \mathbf{J} / \mathbf{m o l} / \mathbf{K}$ \\
\hline 25 & 1.031 & 68.49 & 20.4 & \multirow{5}{*}{146.7} & 423.8 \\
\hline 30 & 1.020 & 16.33 & 17.2 & & 427.4 \\
\hline 35 & 1.068 & 7.987 & 15.6 & & 425.6 \\
\hline 40 & 0.989 & 2.353 & 12.7 & & 428.1 \\
\hline 45 & 1.010 & 1.739 & 12.1 & & 423.3 \\
\hline
\end{tabular}

\subsection{Electrochemical techniques.}

\subsubsection{Open circuit potential $\left(\mathrm{E}_{\mathrm{OC}}\right)$.}

The EOC variation with time for $\mathrm{Zn}$ in the corrosive acid medium without and with different concentrations of $\mathrm{AE}$ was represented in Figure 8. The inspection of Figure 8 indicates that EOC began from $-964.3 \mathrm{mV}$ for the blank solution and moves progressively to the less negative side (anodically) until attaining the steady-state after 10 min because of the dissolution of the oxide film from the $\mathrm{Zn}$ surface. As shown in Figure 8, after adding AE the Eoc began at the more negative potential than the blank solution and, after that, moves anodically. The quickly coming off the steady-state, associated with the blank, is because the oxide film's reductive dissolution on the metal surface formed in the air, followed by a new film's growth inside the solution [38]. The initial shifts of EOC when adding different AE concentrations mean that the resistance of $\mathrm{Zn}$ dissolution in the corrosive acid medium increases with increasing $\mathrm{AE}$ concentration. 


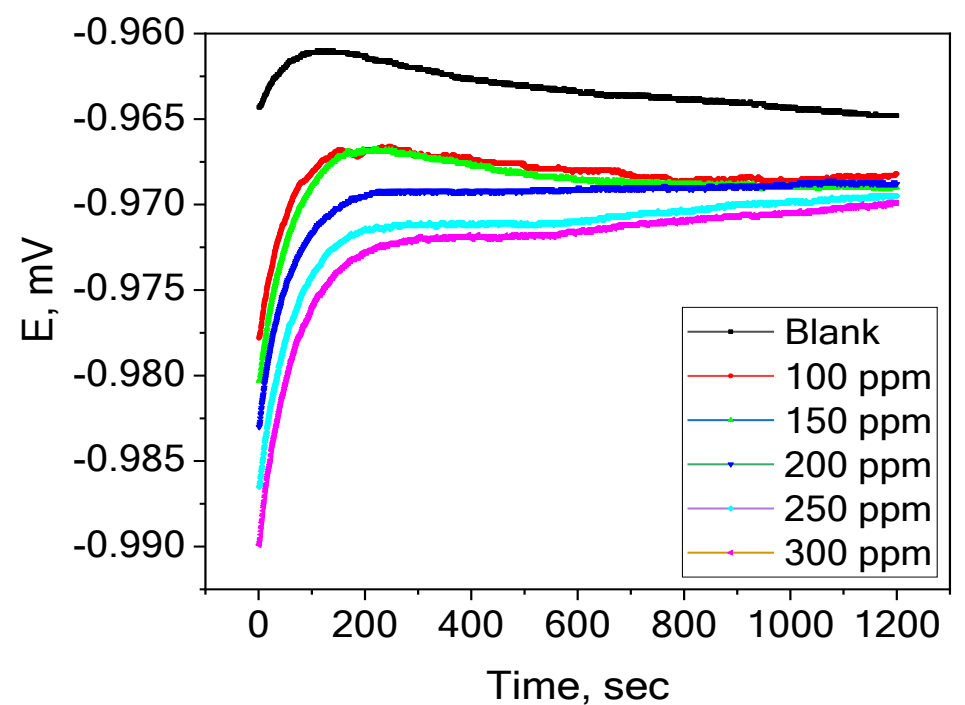

Figure 8. $\mathrm{E}_{\mathrm{OC}}$ vs. time at $25^{\circ} \mathrm{C}$ for $\mathrm{Zn}$ in the corrosive acid medium without and with different $\mathrm{AE}$ concentrations.

\subsubsection{Potentiodynamic polarization (PP) test.}

Anodic and cathodic curves from the PP test at $25{ }^{\circ} \mathrm{C}$ for $\mathrm{Zn}$ in the corrosive acid medium without and with different AE concentrations were recorded in Figure 9. The corrosion current density (icorr) was used for calculating $(\% \mathrm{IE})$ and $(\theta)$ as seen in the next equation [39]:

$\% \mathrm{IE}=\theta \times 100=\left[1-\left(\mathrm{i}_{\text {corr }} / \mathrm{i}^{\mathrm{o}}\right.\right.$ corr $\left.)\right] \times 100$

where $\mathrm{i}_{\text {corr }}$ and $\mathrm{i}^{\mathrm{o}}$ corr are the corrosion current densities with $\mathrm{AE}$ and without it, respectively. Eq. (11) is used to calculate the polarization resistance $\left(R_{p}\right)[40,41]$ :

$\mathrm{R}_{\mathrm{p}}=\left(\beta_{\mathrm{c}} \beta_{\mathrm{a}}\right) /\left[2.303 \mathrm{i}_{\text {corr }}\left(\beta_{\mathrm{c}}+\beta_{\mathrm{a}}\right)\right]$

The corrosion parameters from PP measurements were tabulated in Table 3.

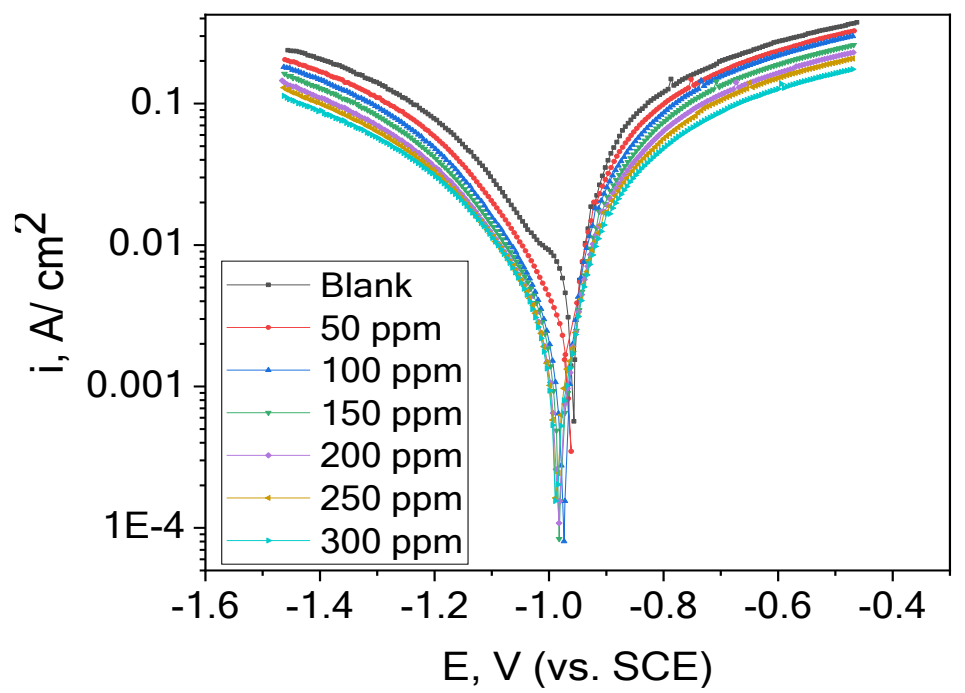

Figure 9. PP curves (anodic and cathodic) for $\mathrm{Zn}$ in the corrosive acid medium without and with different $\mathrm{AE}$ concentrations at $25^{\circ} \mathrm{C}$.

It is clear from Table 3 that the cathodic and anodic Tafel slopes $\left(\beta_{\mathrm{c}} \& \beta_{\mathrm{a}}\right)$ have a little shift compared to the blank corrosive medium, which means that $\mathrm{AE}$ can influence both cathodic and anodic reactions by forming a protective film on the metal surface. The slight change in $\beta_{c}$ and $\beta_{c}$ values shows no change in the inhibition mechanism in the inhibitor's absence and existence [42,43]. As seen from Table 3, the corrosion potential (Ecorr) value change after adding the $\mathrm{AE}$ is fewer than $85 \mathrm{mV}$ that again proves mixed-type inhibition 
$[44,45]$. Table 3 indicates that corrosion current density (icorr) values are lower for inhibited solutions than uninhibited one, and the decrease increasing with the increase in the $\mathrm{AE}$ concentration, indicating that $\mathrm{AE}$ is a good inhibitor for $\mathrm{Zn}$ corrosion in acid media.

Table 3. Electrochemical parameters calculated using PP procedures for $\mathrm{Zn}$ in the acid corrosive medium without and with different $\mathrm{AE}$ concentrations at $25^{\circ} \mathrm{C}$.

\begin{tabular}{|c|c|c|c|c|c|c|c|c|c|}
\hline $\begin{array}{l}C_{\text {inh }}, \\
\text { ppm }\end{array}$ & $\begin{array}{c}-\mathbf{E}_{\mathrm{OCP}} \\
\mathrm{mV}\end{array}$ & $\begin{array}{c}-E_{\text {corr }}, \\
\text { mV vs } \\
\text { SCE }\end{array}$ & $\begin{array}{c}\mathbf{i}_{\text {corr }} \\
\mathbf{m A} / \mathbf{c m}^{2}\end{array}$ & $\begin{array}{c}-\beta_{\mathrm{c}} \\
\mathrm{mV} / \mathrm{dec}\end{array}$ & $\begin{array}{c}\beta_{\mathrm{a}}, \\
\mathrm{mV} / \mathrm{dec}\end{array}$ & $\begin{array}{c}\mathbf{R}_{\mathrm{p}} \\
\text { Ohm } \mathrm{cm}^{2}\end{array}$ & $\begin{array}{c}\text { C.R } \\
\mathrm{mm} / \mathbf{y r}\end{array}$ & $x^{2}$ & $\%$ IE \\
\hline Blank & 962.4 & 959 & 10.70 & 298 & 126 & 3.59 & 6296 & ----- & ----- \\
\hline 50 & 967.1 & 964 & 4.490 & 209 & 93 & 6.22 & 2647 & 0.0050 & 58.0 \\
\hline 100 & 969.6 & 974 & 2.570 & 162 & 89 & 9.73 & 1518 & 0.0071 & 76.0 \\
\hline 150 & 968.0 & 981 & 2.090 & 145 & 88 & 11.33 & 1235 & 0.0081 & 80.5 \\
\hline 200 & 968.7 & 984 & 1.710 & 134 & 85 & 13.20 & 1010 & 0.0089 & 84.0 \\
\hline 250 & 969.5 & 986 & 1.540 & 108 & 84 & 13.29 & 908.7 & 0.0090 & 85.6 \\
\hline 300 & 969.9 & 987 & 1.210 & 93 & 76 & 15.04 & 712.2 & 0.0054 & 88.7 \\
\hline
\end{tabular}

3.2.3. Electrochemical impedance spectroscopy (EIS) test.

Nyquist diagrams (without and with fit) and Bode diagrams for $\mathrm{Zn}$ in the corrosive acid medium without and with different $\mathrm{AE}$ concentrations at $25{ }^{\circ} \mathrm{C}$ were shown in Figure 10a without fitting and Figure $10 \mathrm{~b}$ with fitting and Figure 11, respectively. \% IE and $\theta$ from EIS measurements were calculated as shown below:

$$
\% \mathrm{IE}=\theta \times 100=\left[1-\left(\mathrm{R}_{\mathrm{ct}}^{\mathrm{o}} / \mathrm{R}_{\mathrm{ct}}\right)\right] \times 100
$$

where $\mathrm{R}_{\mathrm{ct}}$ and $\mathrm{R}_{\mathrm{ct}}^{\mathrm{o}}$ represent the charge-transfer resistance with $\mathrm{AE}$ and without it, respectively. EIS parameters are given in Table 4. The equivalent circuit utilized to appropriate the EIS values was given in Figure 12. This circuit consists of stationary phase elements (CPE) rather than capacitors to give many heterogeneity types for corrosion electrodes. The Nyquist plots (Figure 10(a,b)) with and without AE contains a lone capacitive loop signifying the charge transport technique that is extra confirming by single maxima in the corresponding Bode plots. Nyquist plots showed that the semicircle diameter increases with the rise in the concentration of AE. Subsequently, the charge transfer impedance is grown by the corrosion reaction. Nyquist plots' semi-circular shape proves that the process of charge transfer essentially controls the corrosion of $\mathrm{Zn}[46,47]$. The formed AE film on the $\mathrm{Zn}$ surface minimizes the double-layer capacitance $\left(\mathrm{C}_{\mathrm{dl}}\right)$ and increases the charge transfer resistance $\left(\mathrm{R}_{\mathrm{ct}}\right)$. The impedance of a CPE is clarified by the next equation [48]:

$$
Z_{C P E}=Y_{0}^{-1}(j \omega)^{n-1}
$$

where $\mathrm{Y}_{0}$ indicates the CPE quantity and $\omega$ indicates the angular frequency of the maximum impedance for the imaginary component, and $\mathrm{n}$ is the phase shift, which demonstrations information about the surface inhomogeneity, and $\mathrm{j}$ indicates the imaginary number. Higher $\mathrm{n}$ indicates minor surface roughness and vice versa. For $n=0$ represents the resistance, $n=1$ represents the capacitance, $n=-1$ represents the inductance and $n=0.5$ represents the Warburg impedance. In the current study, the values of $\mathrm{n}$ with and without the extracted molecule is between 0.918 and 0.974 . The shift from unity (ideal performance) indicates surface inhomogeneity and surface roughness [49]. The $\mathrm{C}_{\mathrm{dl}}$ for a circuit involving CPE parameters ( $\mathrm{Y}_{0}$ and $\mathrm{n}$ ) were determined using the next eq. [50]: 


$$
\mathrm{C}_{\mathrm{dl}}=\mathrm{Y}_{0}\left(\omega_{\max }\right)^{\mathrm{n}-1}
$$

The parameter $\omega_{\max }$ is express to $2 \pi f$, where $f$ is the frequency of AC. As clear from Table 5, adding different AE concentrations decreases the double layer's capacitance compared to the blank solution. The decrease in the local dielectric constant is because of the replacement of water molecules by the inhibitor [51] and/or the rise in the thickness of the electrical double layer due to the adsorption of extract molecules in the $\mathrm{Zn}$ interface/ solution [52]. Bode plots can also sustain the improved surface smoothness in the existence of extract.
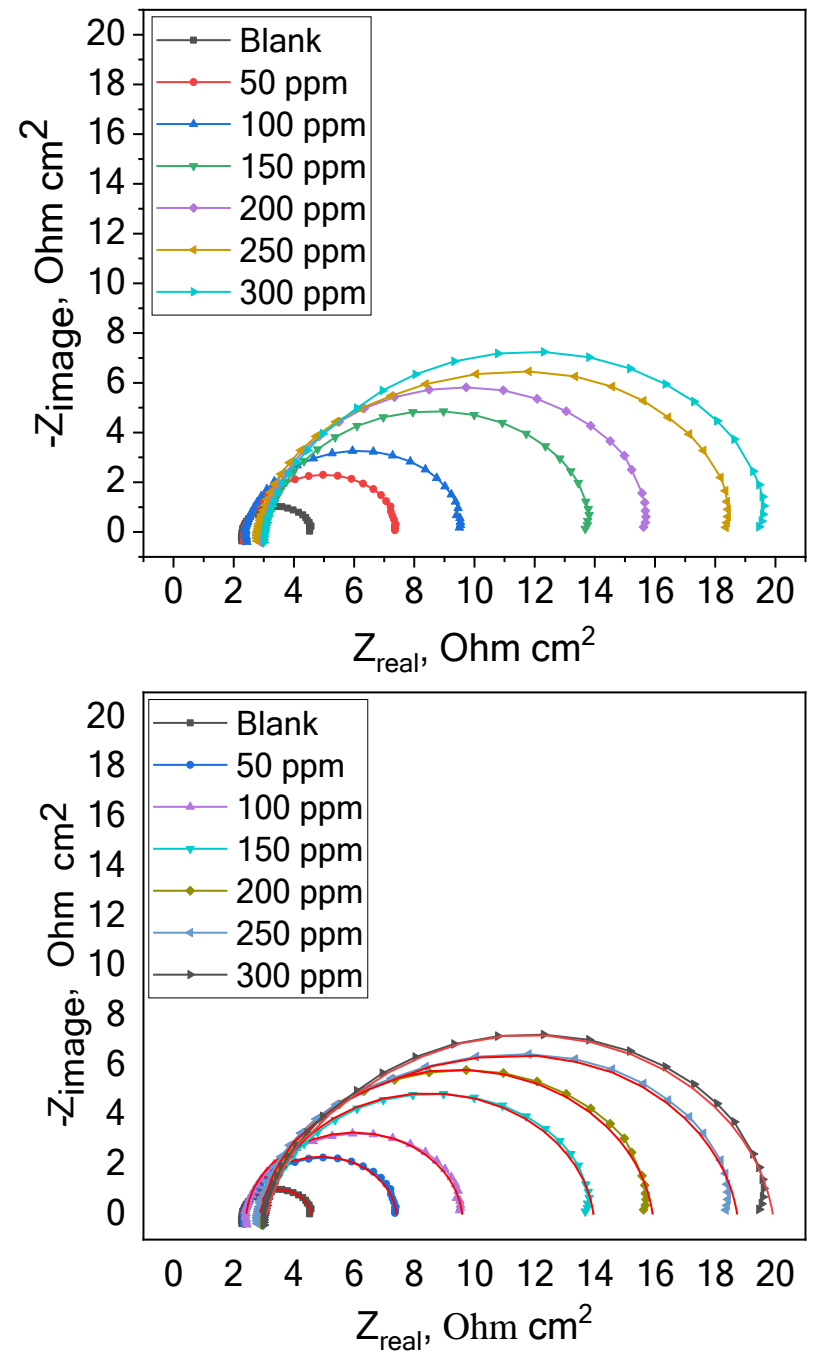

(a)

(b)

Figure 10. The Nyquist plots (a) without fitting; (b) with fitting for $\mathrm{Zn}$ in the corrosive acid medium without and with different $\mathrm{AE}$ concentrations at $25^{\circ} \mathrm{C}$.

The idealistic capacitor is distinguished by a fixed value of -1 and a phase angle of $90^{\circ}$. This deviancy from the previous data is due to the surface roughness. The deviancy from ideal capacitive behavior is more effective in the absence of extract, as seen from Bode plots. The slope and phase angle values are greatly improved in the presence of extract due to the formation of the defensive layer. The phase angle values are more effective at higher extract concentrations [53]. Low values of the goodness of fit $(\chi 2)$ signalize that the fitted data and the experimental data are in high agreement. 


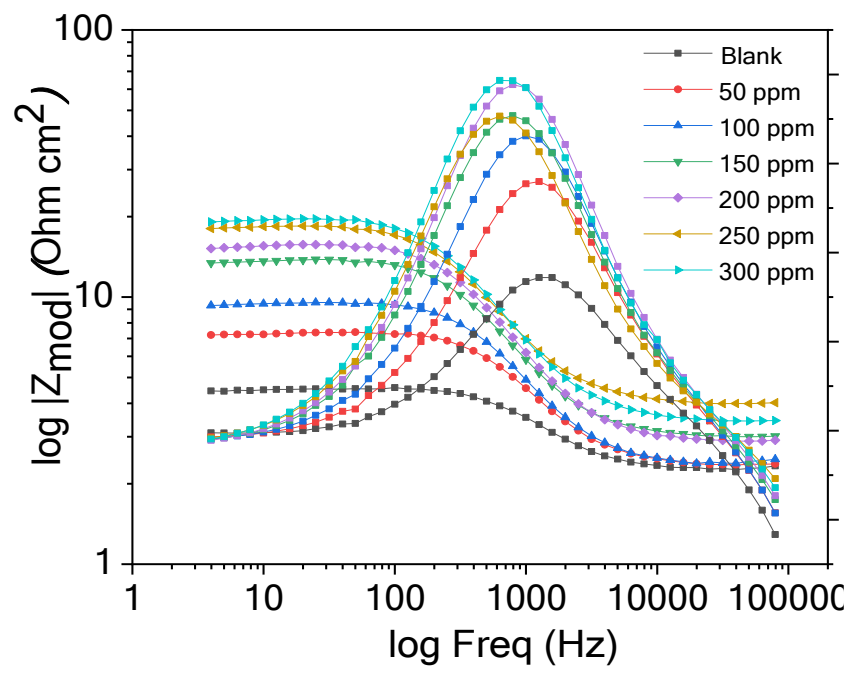

Figure 11. The Bode plots for $\mathrm{Zn}$ in the corrosive acid medium without and with different $\mathrm{AE}$ concentrations at $25{ }^{\circ} \mathrm{C}$.

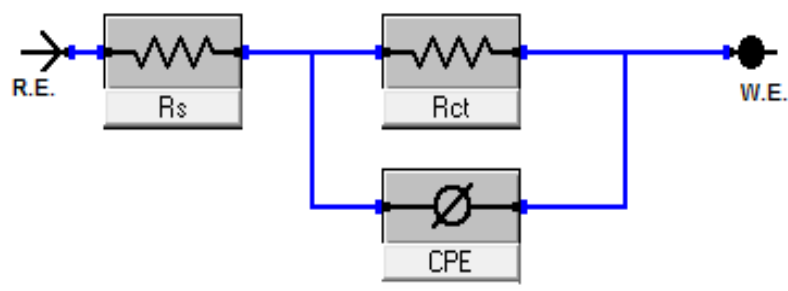

Figure 12. The employed equivalent circuit for appropriate the EIS values.

Table 4. The parameters gained from EIS procedures for $\mathrm{Zn}$ in the corrosive acid medium without and with

\begin{tabular}{|c|c|c|c|c|c|c|c|}
\hline $\begin{array}{l}\text { Cinh, } \\
\text { ppm }\end{array}$ & $\begin{array}{c}\mathbf{R}_{\mathrm{ct}}, \\
\text { Ohm } \mathbf{c m}^{2}\end{array}$ & $\begin{array}{c}R_{u,} \times 1^{3} \\
\text { Ohm } \mathbf{c m}^{2}\end{array}$ & $\begin{array}{c}Y_{0}, \\
\mu S^{n} / O h m \mathbf{c m}^{2}\end{array}$ & $\mathbf{N}$ & $\begin{array}{c}C_{\mathrm{dl}}, \\
\mu \mathrm{F} / \mathrm{cm}^{2}\end{array}$ & $\boldsymbol{\theta}$ & $\% \mathrm{IE}$ \\
\hline Blank & $2.223 \pm 0.054$ & $2.304 \pm 0.020$ & $93.51 \pm 18.4$ & $0.974 \pm 0.022$ & 74.84 & ------ & ----- \\
\hline 50 & $5.024 \pm 0.069$ & $2.384 \pm 0.019$ & $70.98 \pm 7.9$ & $0.954 \pm 0.013$ & 48.24 & 0.558 & 55.8 \\
\hline 100 & $7.172 \pm 0.090$ & $2.419 \pm 0.019$ & $67.98 \pm 6.2$ & $0.948 \pm 0.010$ & 44.78 & 0.690 & 69.0 \\
\hline 150 & $10.93 \pm 0.139$ & $3.030 \pm 0.024$ & $65.78 \pm 5.8$ & $0.929 \pm 0.010$ & 40.97 & 0.797 & 79.7 \\
\hline 200 & $13.01 \pm 0.157$ & $2.916 \pm 0.023$ & $61.50 \pm 4.6$ & $0.931 \pm 0.009$ & 36.16 & 0.829 & 82.9 \\
\hline 250 & $14.71 \pm 0.188$ & $4.021 \pm 0.031$ & $60.62 \pm 5.7$ & $0.916 \pm 0.010$ & 38.29 & 0.849 & 84.9 \\
\hline 300 & $16.46 \pm 0.196$ & $3.459 \pm 0.027$ & $58.93 \pm 4.5$ & $0.918 \pm 0.008$ & 34.65 & 0.865 & 86.5 \\
\hline
\end{tabular}

\subsubsection{Electrochemical frequency modulation (EFM).}

Intermodulation spectra of $\mathrm{Zn}$ in the corrosive acid medium without and with different $\mathrm{AE}$ concentrations at $25^{\circ} \mathrm{C}$ were displayed in Figure 13. The more prominent peaks were utilized to compute $\mathrm{i}_{\mathrm{corr}}, \beta_{\mathrm{c}}, \beta_{\mathrm{a}}$, and the causality factors $(\mathrm{CF}-2, \mathrm{CF}-3) . \% \mathrm{IE}$ and $\theta$ can be calculated from EFM measurements as illustrated in eq. (10). Parameters gotten from EFM procedures were recorded in Table 5. The decrease in $i_{\text {corr }}$ with the increase in AE concentration decreases C.R. and increases in $\Theta, \%$ IE. The closest of CF-2 and CF-3 from theoretical values (2.0 and 3.0) reinforce the validity of Tafel slopes and $i_{\text {corr }}$; this accords with the EFM theory $[54,55]$. 

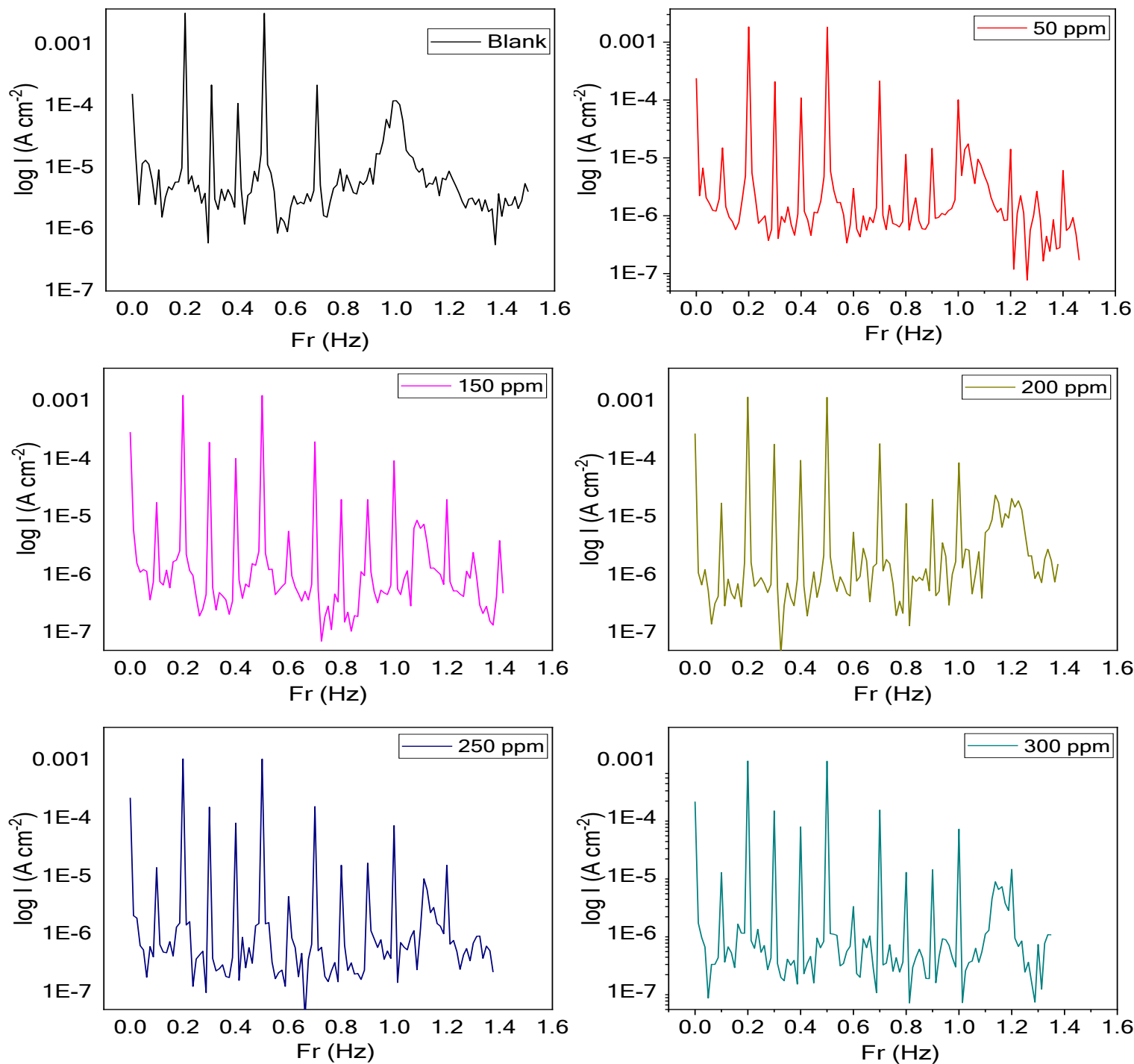

Figure 13. EFM spectra for $\mathrm{Zn}$ in the corrosive acid medium without and with different $\mathrm{AE}$ concentrations at 25 ${ }^{\circ} \mathrm{C}$.

Table 5. The parameters gained from EFM procedures for $\mathrm{Zn}$ in the corrosive acid medium without and with different $\mathrm{AE}$ concentrations at $25^{\circ} \mathrm{C}$.

\begin{tabular}{|c|c|c|c|c|c|c|c|c|}
\hline $\begin{array}{l}C_{\text {inh }}, \\
\text { ppm }\end{array}$ & $\begin{array}{c}\mathbf{i}_{\text {corr }}, \\
\mathbf{m A} / \mathbf{c m}^{2}\end{array}$ & $\begin{array}{c}-\beta_{\mathrm{c}} \\
\mathrm{mV} / \mathrm{dec}\end{array}$ & $\begin{array}{c}\boldsymbol{\beta}_{\mathrm{a}} \\
\mathrm{mV} / \mathrm{dec}\end{array}$ & $\begin{array}{l}\text { C.R, } \\
\text { mpy }\end{array}$ & CF-2 & CF-3 & $\boldsymbol{\theta}$ & $\%$ IE \\
\hline Blank & 20.70 & 394 & 224 & 23030 & 1.884 & 2.806 & -------- & ------- \\
\hline 50 & 6.335 & 111 & 126 & 7051 & 2.000 & 3.026 & 0.694 & 69.4 \\
\hline 100 & 5.189 & 188 & 108 & 5775 & 2.009 & 3.160 & 0.749 & 74.9 \\
\hline 150 & 2.842 & 484 & 86 & 3163 & 2.007 & 2.988 & 0.863 & 86.3 \\
\hline 200 & 2.485 & 393 & 83 & 2765 & 2.004 & 3.036 & 0.880 & 88.0 \\
\hline 250 & 2.385 & 433 & 87 & 2654 & 2.002 & 3.234 & 0.885 & 88.5 \\
\hline 300 & 2.339 & 496 & 94 & 2607 & 2.002 & 3.056 & 0.887 & 88.7 \\
\hline
\end{tabular}

\subsection{Surface examination.}

3.3.1. Scanning electron microscopy (SEM) examination.

The SEM image of Zn sample before exposure to the corrosive acid medium was shown in Figure 14(a). Figure 14(b, c) shows the SEM images for Zn surface after exposure to the corrosive acid medium without and with $300 \mathrm{ppm}$ of AE, respectively. It is shown from Figure 14(b) that the $\mathrm{Zn}$ surface was suffering from a severe corrosion attack caused by the corrosive acid medium. The morphology of Zn surface in the presence of AE (Figure 14(c)) indicates a 
smoother surface and a change in thickness. This is because of the AE molecules' adsorption on the surface and the formation of a protective film dispersed randomly on the $\mathrm{Zn}$ surface, leading to lowering the contact between the metal and the corrosive medium, thus protecting the surface against corrosion [56].

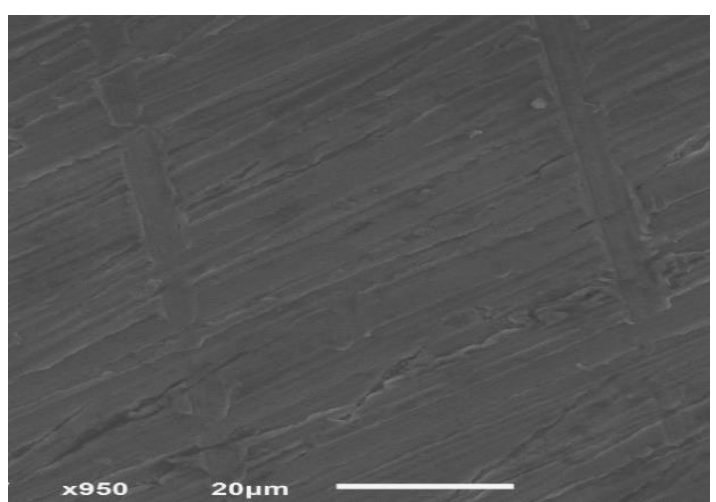

(a)

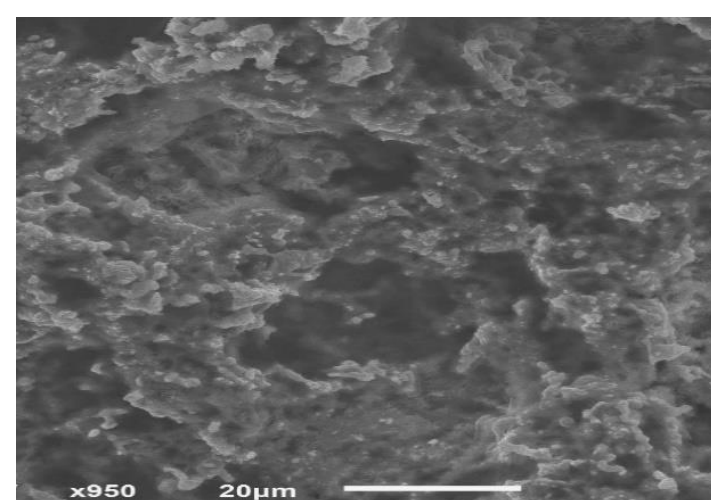

(b)

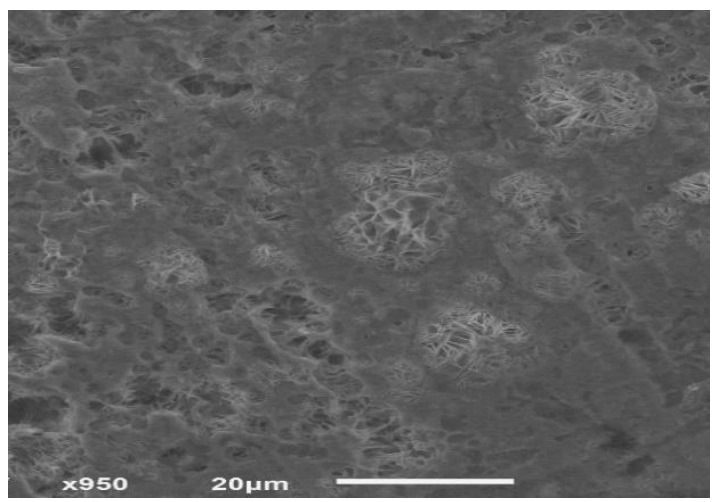

(c)

Figure 14. SEM micrographs of (a) free Zn; (b) Zn after 24 hrs. of exposure to the acid corrosive medium only, and (c) $\mathrm{Zn}$ after $24 \mathrm{hrs}$. of exposure to the corrosive acid medium with $300 \mathrm{ppm}$ of AE.

\subsubsection{Energy dispersion X-ray (EDX) analysis.}

The EDX spectra of free Zn was shown in Figure 15(a). There is O on the $\mathrm{Zn}$ surface that indicates the formation of a passive film of $\mathrm{ZnO}$ on the surface. Figure 15(b, c) shows the EDX spectra for Zn surface after exposure to the corrosive acid medium without and with 300 ppm of AE, respectively. For blank (Figure 15(b)), the spectra demonstrated the existence of $\mathrm{C}, \mathrm{O}, \mathrm{Cd}, \mathrm{Pb}$, and $\mathrm{Cl}$ (gained from $\mathrm{HCl}$ medium). The spectra of the inhibited surface (Figure 15(c)) indicate the presence of $\mathrm{O}$, and $\mathrm{C}$ (owing to the carbon atoms of $\mathrm{AE}$ ). The mass percent of elements present in the spectra were recorded in Table 6.

Table 6. Surface composition (mass \%) of $\mathrm{Zn}$ before and after 24 hours of exposure to the corrosive acid medium without and with $300 \mathrm{ppm}$ of AE.

\begin{tabular}{c|c|c|c|c|c|c} 
(Mass\%) & Zn & C & O & Cl & Cd & Pb \\
\hline Free Zn & 87.57 & 10.14 & 2.30 & --- & --- & --- \\
\hline Zn in blank & 57.18 & 4.89 & 19.21 & 3.17 & 6.94 & 8.61 \\
\hline Inhibited Zn surface & 73.11 & 8.59 & 14.56 & 3.73 & --- & --
\end{tabular}




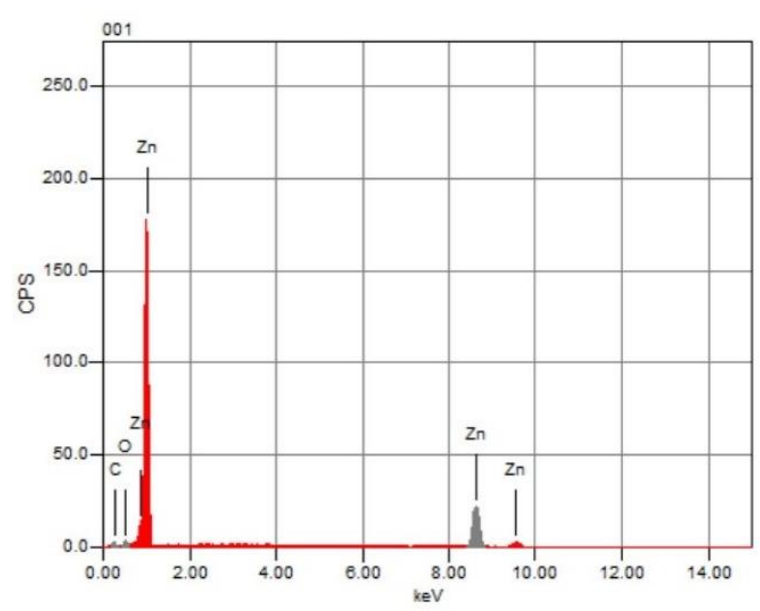

(a)

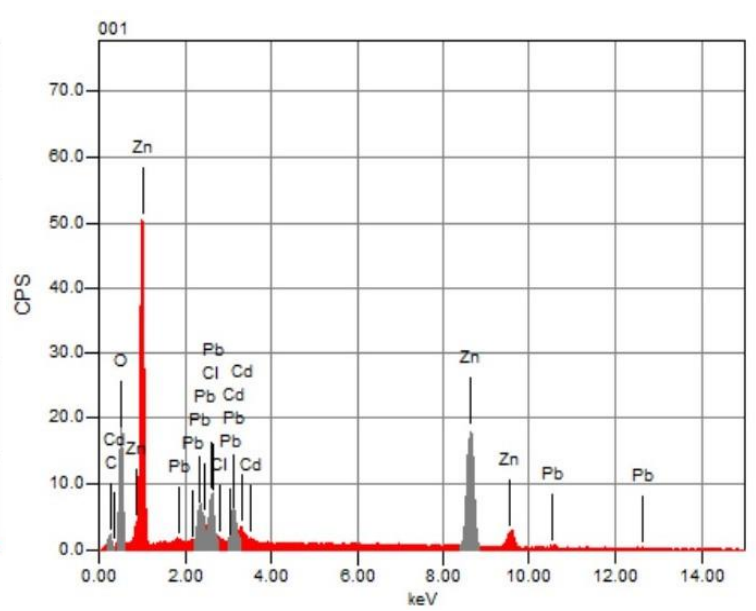

(b)

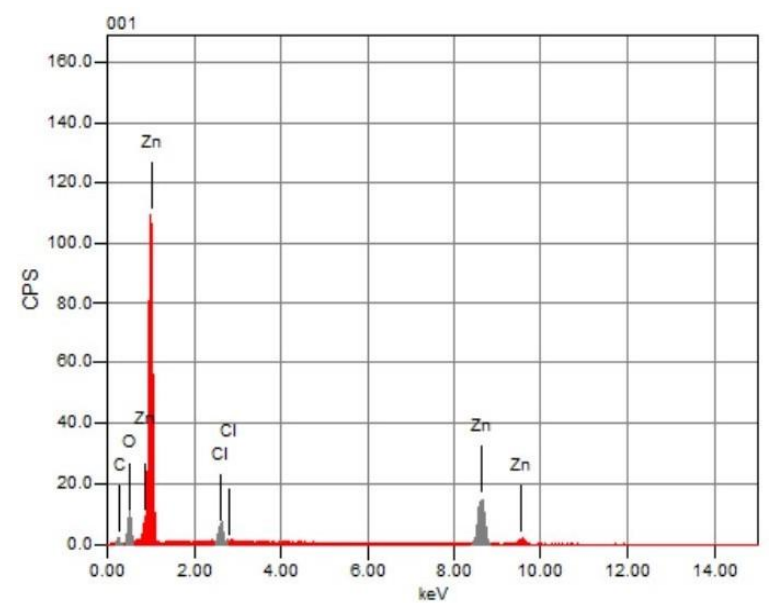

(c)

Figure 15. EDX analysis for (a) free $\mathrm{Zn}$, (b) $\mathrm{Zn}$ after $24 \mathrm{hrs.} \mathrm{of} \mathrm{exposure} \mathrm{to} \mathrm{the} \mathrm{corrosive} \mathrm{acid} \mathrm{medium} \mathrm{only,} \mathrm{and}$ (c) $\mathrm{Zn}$ after $24 \mathrm{hrs}$. of exposure to the acid corrosive medium with $300 \mathrm{ppm}$ of AE.

3.3.3. Atomic force microscopy (AFM) analysis.

The AFM test is the most important study for analyzing metal surfaces, which is employed to further examine the formed protective film on the surface [57]. Figure 16(a) appears the two -dimensional (2d) and three-dimensional (3d) AFM images of the Zn surface before exposure to acid (free sample). This figure displays the surface of $\mathrm{Zn}$ adequately smooth and reflects light. The two -dimensional (2d) and the three-dimensional (3d) AFM images of Zn metal after exposure to acid only (blank sample) and after exposure to the acid with 300 ppm of AE (inhibited sample) are shown in Figure 16(b, c), respectively. Roughness parameters for free, blank and inhibited $\mathrm{Zn}$ surface were given in Table 7. The lower roughness was detected on the free sample.

Table 7. Roughness parameters for free, blank and inhibited $\mathrm{Zn}$ surface.

\begin{tabular}{c|c|c|c} 
Roughness parameters & Free Zn & Zn in blank & inhibited Zn surface \\
\hline $\mathrm{Sa}$ & $79.718 \mathrm{~nm}$ & $617.3 \mathrm{~nm}$ & $164.76 \mathrm{~nm}$ \\
\hline $\mathrm{Sq}$ & $99.615 \mathrm{~nm}$ & $773.68 \mathrm{~nm}$ & $225.71 \mathrm{~nm}$ \\
\hline $\mathrm{Sy}$ & $722.38 \mathrm{pm}$ & $4.1713 \mu \mathrm{m}$ & $5.7779 \mu \mathrm{m}$ \\
\hline $\mathrm{Sp}$ & $349.42 \mathrm{pm}$ & $2071.4 \mathrm{~nm}$ & $1344.8 \mathrm{~nm}$ \\
\hline $\mathrm{Sv}$ & $-372.96 \mathrm{pm}$ & $-2099.9 \mathrm{~nm}$ & $-4.433 \mu \mathrm{m}$ \\
\hline $\mathrm{Sm}$ & $-20.019 \mathrm{pm}$ & $-10.455 \mathrm{fm}$ & $-9.686 \mathrm{fm}$
\end{tabular}


The height and roughness of the metal with the extract are less than the blank sample's height and roughness. As the roughness decreases, the inhibitor inhibits corrosion in a higher percent [58]. The lower value of roughness for inhibited solution than uninhibited one is because the adsorption of the inhibitor on the metal surface helps for its protection from getting corroded [59].

$3 d$

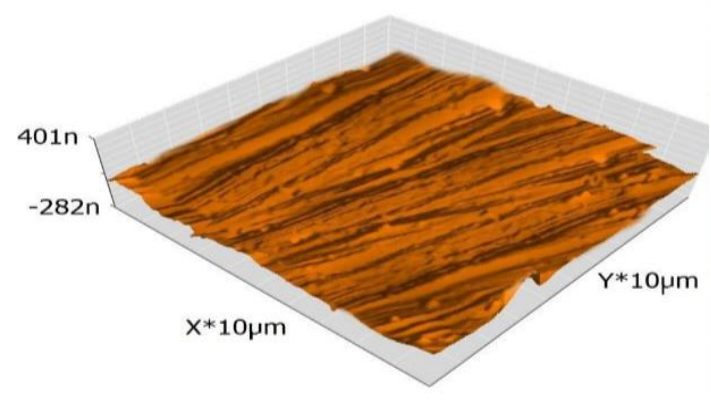

$2 d$

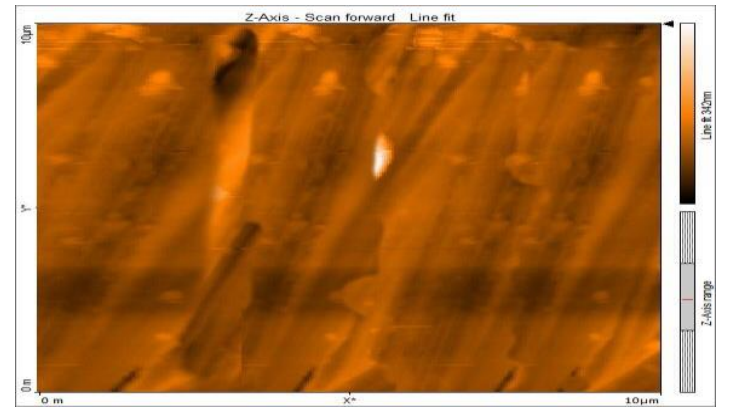

(a) free sample
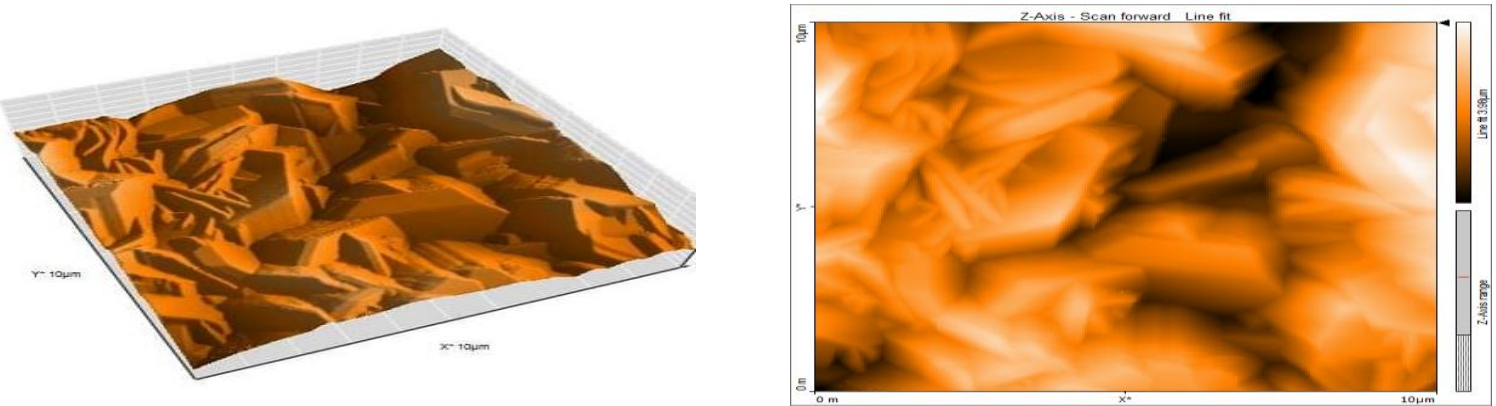

(b) blank sample
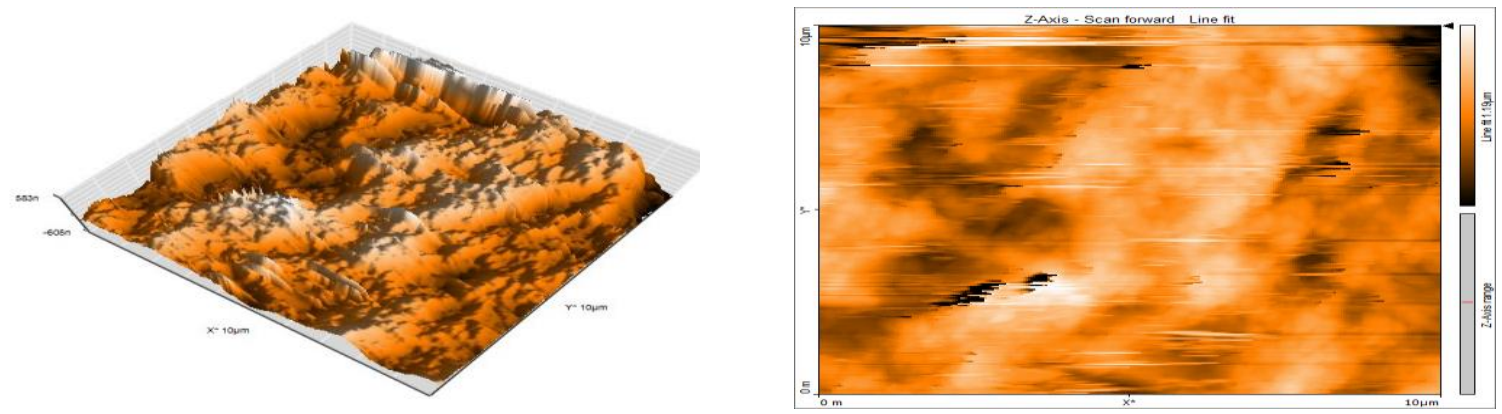

(c) inhibited sample

Figure 16. Thethree-dimensional (3d) and the two -dimensional (2d) AFM images of (a) free sample; (b) blank sample; (c) inhibited sample.

\subsubsection{Fourier-transform infrared spectroscopy (FT-IR).}

The FT-IR spectrophotometer is a useful instrument employed to recognize the functional groups present in the extract and the type of interaction between the function group and metal surface [60]. Figure 17 displays broad peaks of AE at $(3331,2973,1670,1381,1088$, and $880 \mathrm{~cm}^{-1}$ ), which correspond to $\mathrm{O}-\mathrm{H}$, carboxylic acid $\mathrm{O}-\mathrm{H}$ stretching vibration, $\mathrm{C}=\mathrm{O}, \mathrm{C}-$ $\mathrm{H}, \mathrm{C}-\mathrm{O}$, aromatic $\mathrm{C}-\mathrm{H}$ bending vibration, respectively. It is clear that there is some peaks displacement between the spectra of the $\mathrm{AE}$ and the adsorbed extract from the $\mathrm{Zn}$ surface after corrosion. Also, a few peaks are either disappearing or becoming less eminent [61]. This indicates the interaction of $\mathrm{AE}$ with $\mathrm{Zn}$ through the functional groups present in $\mathrm{AE}$ molecules, resulting in the inhibition process. 


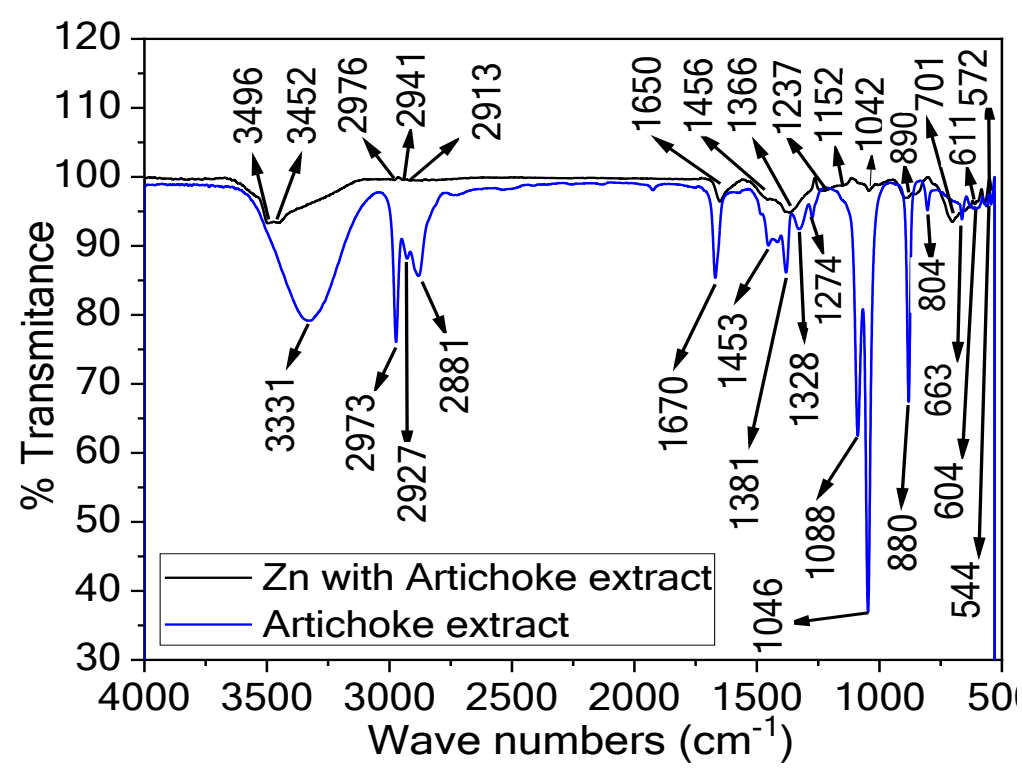

Figure 17. FT-IR spectra for AE and for Zn metal after immersion in the inhibited acid corrosive medium.

\subsubsection{UV spectroscopy.}

UV-visible spectroscopic checking can be employed to affirm the prospect of complex formation between metal and inhibitor.

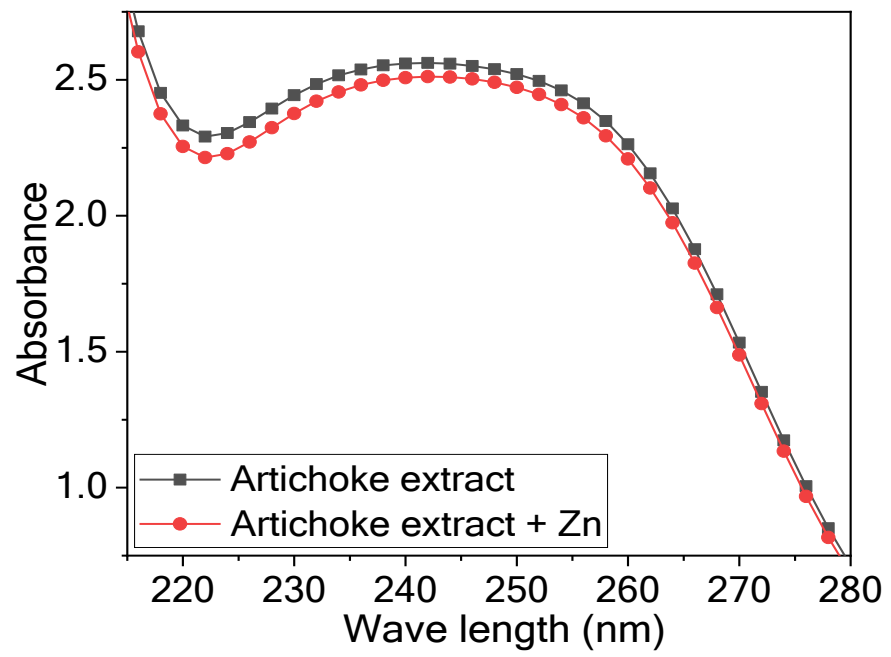

Figure 18. UV-visible absorption spectra of inhibited acid corrosive medium without and with $\mathrm{Zn}$ immersion.

The spectra of UV-visible absorption for the corrosive acid medium with $300 \mathrm{ppm}$ of $\mathrm{AE}$ without and with $\mathrm{Zn}$ immersion are seen in Figure 18. There is a shift in absorbance after $\mathrm{Zn}$ immersion. This reveals the formation of a complex between $\mathrm{AE}$ and $\mathrm{Zn}$ that is responsible for the inhibition activity. Generally, the alteration in the maximum absorbance position and the absorbance value denotes forming a complex between within solution between two species [62]. The shape of the spectra with $\mathrm{Zn}$ and without its immersion has no significant variation. It indicates the physical adsorption of the $\mathrm{AE}$ on the $\mathrm{Zn}$ surface.

\subsection{Biological effect.}

The biological effect of acute toxicity tests was done for artichoke extract using the Doc-it colony instrument. Original photos of bacteria colonies and the photos using the instrument, for blank and AE, were demonstrated in Figure 19. The number of bacteria colonies cultivated obtained using the Doc-it colony instrument was shown in Table 8 . The results of 
Table 8 show that the number of bacteria colonies for AE ( 88 colonies) was lesser than the blank (287 colonies), meaning that AE has a kindly impact in preventing multiplying bacteria, and so the CR decreased.

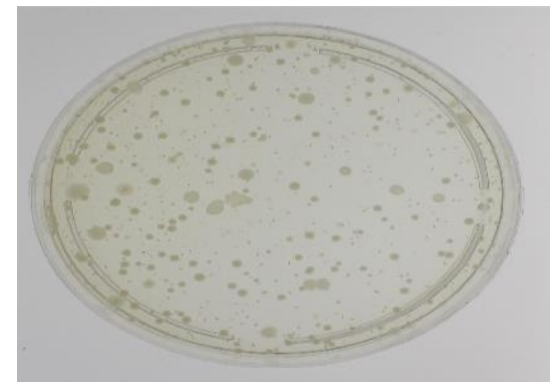

(a1) original photo for blank

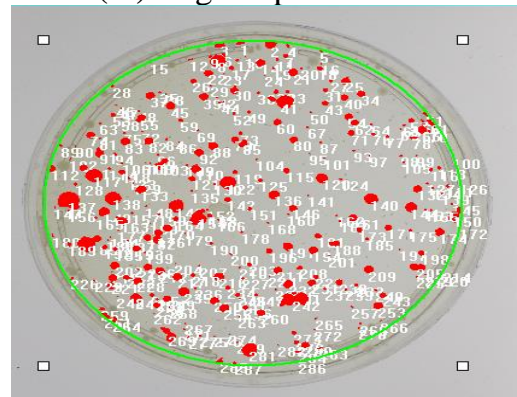

(b1) photo by Doc-it instrument for blank

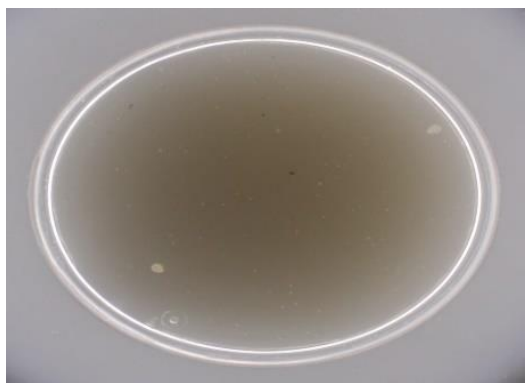

(a) original photo for $\mathrm{AE}$

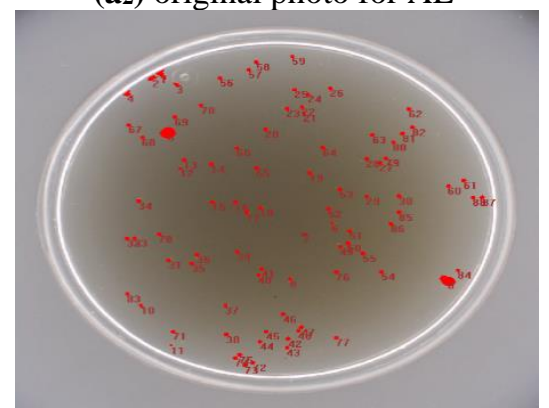

(b2) photo by Doc-it instrument for AE

Figure 19. Original photos of bacteria colonies for $\left(\mathbf{a}_{1}\right)$ blank; (a2) AE; photos by Doc-it colony instrument for (b1) blank; (b2) AE.

Table 8. Number of bacteria colonies for blank and for AE as obtained using Doc-it colony counter instrument.

\begin{tabular}{c|c} 
Sample & No of bacteria colonies \\
\hline Blank & 287 \\
\hline AE & 88
\end{tabular}

\subsection{Quantum mechanics and molecular dynamics simulations studies.}

\subsubsection{Quantum mechanics.}

The plant extract contains many compounds in low ratios. But, there are two major compounds, they are Apigenin and Luteolin. Their chemical composition as shown in Table 9. Figure 20 shows the optimum geometry structure of LUMO \& HOMO orbitals for Apigenin and Luteolin compounds.

Table 9. Chemical structure, Chemical formula, and molar mass of Apigenin and Luteolin.

\begin{tabular}{|c|c|c|}
\hline & Apigenin & Luteolin \\
\hline \multicolumn{3}{|l|}{$\begin{array}{l}\text { Chemical } \\
\text { structure }\end{array}$} \\
\hline IUPAC name & $\begin{array}{l}\text { 5,7-Dihydroxy-2-(4-hydroxyphenyl)-4H-1- } \\
\text { benzopyran-4-one }\end{array}$ & $\begin{array}{l}\text { 2-(3,4-Dihydroxyphenyl)- 5,7-dihydroxy-4- } \\
\text { chromenone }\end{array}$ \\
\hline Chemical formula & $\mathrm{C}_{15} \mathrm{H}_{10} \mathrm{O}_{5}$ & $\mathrm{C}_{15} \mathrm{H}_{10} \mathrm{O}_{6}$ \\
\hline Molar mass & $270.240 \mathrm{~g} \cdot \mathrm{mol}^{-1}$ & $286.239 \mathrm{~g} \cdot \mathrm{mol}^{-1}$ \\
\hline
\end{tabular}




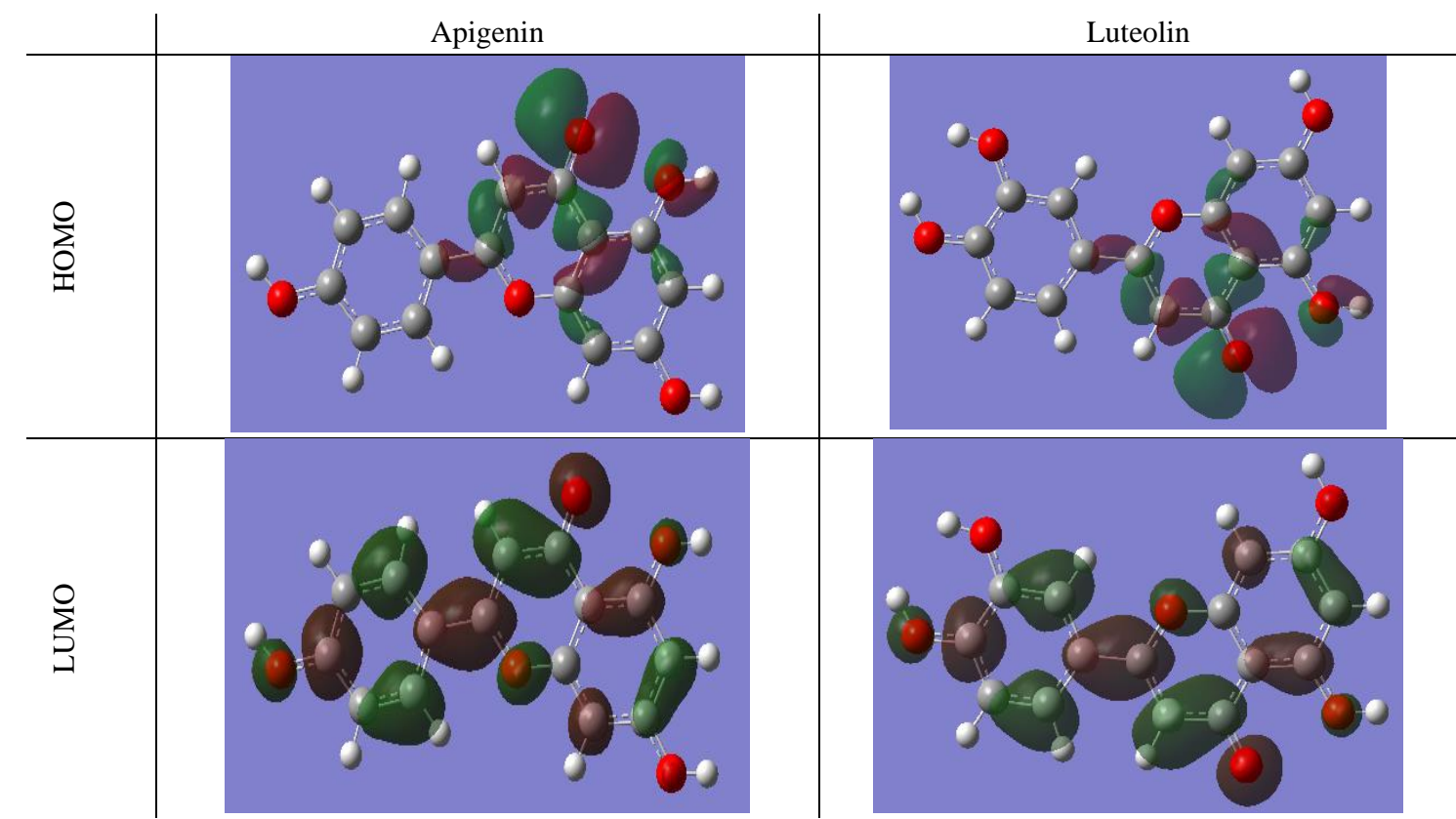

Figure 20. The optimum geometry structure and LUMO \& HOMO orbitals for Apigenin and Luteolin compounds.

\subsubsection{Dynamics simulations studies.}

Figure 21 illustrates the suitable arranging to absorb AE constituents on the Fe $\left(\begin{array}{lll}1 & 1 & 0\end{array}\right)$ substrate. Table 11 shows the simulation of Monte Carlo resulting; distortion energies, total energy and solid adsorption. Total energy (substrate energy) is the totality of the energy of solid adsorption, molecules, and deformation energy. The substrate energy is taken as zero. In addition, the adsorption energy shows the gained or wanted energy when the comfortable adsorption of $\mathrm{AE}$ compounds takes place on the substrate. The rigid adsorption energy shows the gained or wanted energy when the uncomfortable adsorption of AE compounds has happened. It has occurred before the geometry optimization adsorption has occurred onto the substrate. It takes place before occurring the geometry optimization adsorption onto the substrate. The deformation energy is liberalized when the adsorption of AE compounds is restful on the substrate. The energy of substrate - adsorbate conformations (dEads / dNi) exhibits that one of the adsorbed compounds is taken away [69]. The results in Table 11 confirm that the examined AE shows high adsorption on the $\mathrm{Zn}$ surface.

Table 10 illustrates the quantum chemistry parameters (Elumo, Eномо, dipole moment $(\mu)$, and energy gap $(\Delta \mathrm{E}))$ for $\mathrm{AE}$ constituents. Еномо signifies the susceptibility of molecules to grant electrons to the $\mathrm{d}$ orbital of $\mathrm{Zn}$, so molecules with high Еномо values have the potency to grant electrons to the metal surface. Negative Eномо values signalize physical adsorption rather than chemical one $[63,64]$. ELUMO represents the capability of metal orbital to gain an electron, and its low value shows more capability for electrons accepting [65,66]. An inverse relationship between molecule reactivity and energy gap $(\Delta \mathrm{E})$ means that the smaller energy gap shows good corrosion inhibition because the ionization energy needed to eliminate the electron from the exterior orbit shell is low. The dipole moment $(\mu)$ represents the electrons distribution in the molecule, and it is a measure of the bond polarity [67]. A high $\mu$ indicates a strong dipole-dipole interaction with the $\mathrm{Zn}$ surface and tool up a good corrosion inhibition [68]. The quantum studies results confirm the experimental outcomes and show good inhibition of $\mathrm{AE}$ towards $\mathrm{Zn}$ corrosion. 
Table 10. The quantum chemistry parameters $\left(\mathrm{E}_{\mathrm{LUMO}}, \mathrm{E}_{\mathrm{HOMO}}\right.$, dipole moment $(\mu)$, and $\Delta \mathrm{E}$ energy cavity) for $\mathrm{AE}$ constituents.

\begin{tabular}{c|c|c|c|c} 
Comp. & Eномо (ev) & ELumo $_{\text {(ev) }}$ & $\boldsymbol{\Delta E}(\mathbf{e v})$ & Dipole moment (Debye) \\
\hline Apigenin & -5.505 & -1.361 & 4.144 & 2.4448 \\
\hline Luteolin & -5.475 & -1.348 & 4.127 & 7.1421 \\
& Side View & & \multicolumn{2}{|c}{ Top View }
\end{tabular}
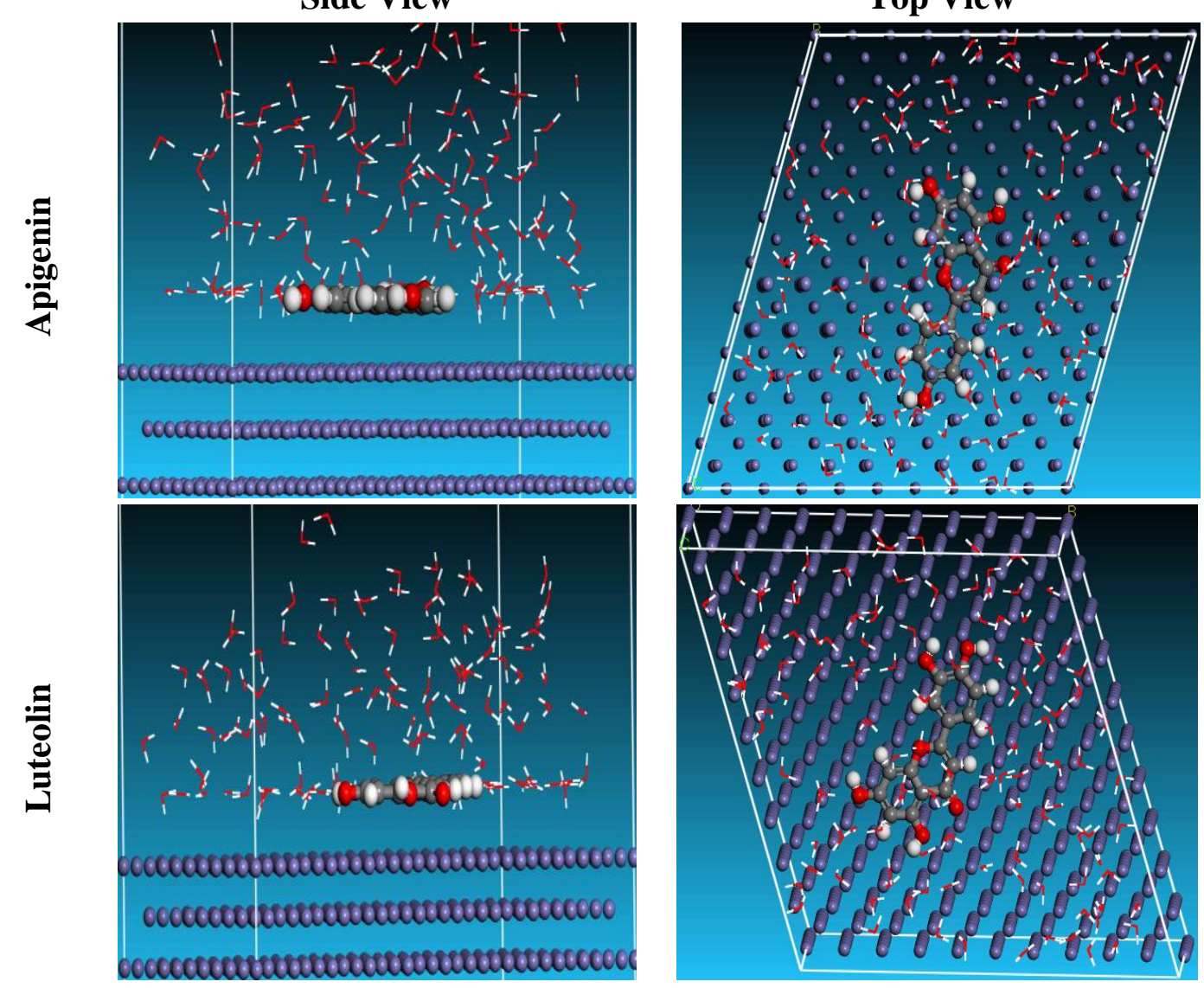

Figure 21. The suitable arranging to absorb AE constituents on the Fe $\left(\begin{array}{lll}1 & 1 & 0\end{array}\right)$ substrate.

Table 11. The simulation of Monte Carlo resulting; distortion energies, total energy, and solid adsorption.

\begin{tabular}{c|c|c|c|c|c|c} 
Structures & $\begin{array}{c}\text { Total } \\
\text { Energy }\end{array}$ & $\begin{array}{c}\text { Adsorption } \\
\text { Energy }\end{array}$ & $\begin{array}{c}\text { Rigid } \\
\text { adsorption } \\
\text { energy }\end{array}$ & $\begin{array}{c}\text { Deformation } \\
\text { Energy }\end{array}$ & $\begin{array}{c}\text { Compound } \\
\mathbf{d E a d} / \mathbf{d N i}\end{array}$ & $\begin{array}{c}\mathbf{H}_{2} \mathbf{O} \\
\mathbf{d E a d} / \mathbf{d N i}\end{array}$ \\
\hline $\begin{array}{c}\mathrm{Fe}(1 \quad 10) / \\
\text { Apigenin/ } / \mathrm{H}_{2} \mathrm{O}\end{array}$ & -3228.3 & -3154.7 & -3312.5 & 157.8 & -185.6 & -8.3 \\
\hline $\begin{array}{c}\mathrm{Fe}(1 \quad 10) / \text { Luteolin } \\
/ \mathrm{H}_{2} \mathrm{O}\end{array}$ & -3290.0 & -3217.4 & -3372.8 & 155.3 & -200.1 & -8.8 \\
& & & & & &
\end{tabular}

\subsection{Inhibition mechanism analysis.}

From the experiment results, the corrosion inhibition mechanism for $\mathrm{Zn}$ in the corrosive acid medium using AE can be explained from the view of adsorption. The main constituents of $\mathrm{AE}$ are Apigenin and Luteolin, which contain the oxygen atoms, hydroxyl groups, and three benzene rings in their structures. The adsorption process can be deemed as a mono exchange process in which the aqueous molecule (I) replaces several adsorbed water molecules (x) on the metal surface [70]:

$$
\mathrm{I}_{(\mathrm{aq})}+\mathrm{X} \mathrm{H}_{2} \mathrm{O}(\text { sur }) \rightarrow \mathrm{I}_{(\text {sur })}+\mathrm{x} \mathrm{H}_{2} \mathrm{O}_{(\mathrm{aq})}
$$

The adsorption process can be affected by factors such as; charged surface, inhibitor structure, and the scuttled charge along the inhibitor molecule. The adsorption may be a 
physisorption or chemisorption reaction. Generally, the physisorption process needs the existence of charged metal surfaces and charged molecules. At firstly, the anionic acid species were adsorbed on the $\mathrm{Zn}$ surface, making the surface negative. The protonated extract components can then be adsorbed on the surface. In the chemisorption process, the coordinate bond is formed between the extract and the metal surface by sharing or transferring the charge.

The existence of transition metal with unoccupied orbital and extracts with chemical constituents containing $\pi$-electrons and hetero atoms with a free lone pair of electrons (ex. $\mathrm{N}$, $\mathrm{O}, \mathrm{S})$ is necessary and widely aid in the adsorption process [71].

\section{Conclusions}

AE showed good \% IE reached $93.2 \%$ at $300 \mathrm{ppm}$ concentration. Adsorption of extract on $\mathrm{Zn}$ surface obeyed Langmuir isotherm. The inhibition action improved with increasing $\mathrm{AE}$ concentrations and decreased as the temperature increases. The adsorption of AE on $\mathrm{Zn}$ surface accords with Langmuir adsorption isotherm. Potentiodynamic polarization tests detected the extract worked as a mixed-type inhibitor with cathodic dominance. EIS tests displayed that a protective layer was formed on the $\mathrm{Zn}$ surface. This accords with the decrease in the $\mathrm{C}_{\mathrm{dl}}$ value and the increase of the $R_{p}$ with increasing AE concentration. The SEM/EDX, FTIR, and AFM examine presented a protective film of extract molecules above the $\mathrm{Zn}$ surface. The shape of UV spectroscopic indicated physisorption. The biological effect indicated that the number of Bacteria colonies for AE was lesser than the blank. Quantum mechanics and molecular dynamics simulation studies confirm the experimental results. Based on all outcomes of the applied techniques, it is attained that the employed extract works as a good corrosion inhibitor for zinc in acid solution, and its efficiency in the inhibition process raises with the increase in its concentration and decreases with the temperature rise.

\section{Funding}

This research received no external funding.

\section{Acknowledgments}

The authors are grateful to the Chemistry Department (especially corrosion laboratory), Faculty of Science, Mansoura University, for providing laboratory facilities for completing this work.

\section{Conflicts of Interest}

The authors declare no conflict of interest.

\section{References}

1. Garcia, G.; Cavallaro, L.; Broussalis, A.; Ferraro, G.; Martino, V.; De Torres, R.; Coussio, J.; Campos, R. Antiviral activity of Achyrocline flaccida Wein DC aqueous extract. Phytotherapy Research 1995, 9, 251254, https://doi.org/10.1002/ptr.2650090404.

2. Manov, S.; Noli, F.; Lamazouere, A.M.; Aries, L. Surface treatment for zinc corrosion protection by a new organic chelating reagent. Journal of Applied Electrochemistry 1999, 29, 995-1003, https://doi.org/10.1023/A:1003585816876.

3. Wranglen, G. An introduction to corrosion and protection of metals; 1985.

4. Fouda, A.S.; Shalabi, K.; Nofal, A.M.; Elzekred, M.A. Methanol Extract of Rumex Vesicarius L. as EcoFriendly Corrosion Inhibitor for Carbon Steel in Sulfuric Acid Solution. Chemical Science Transactions 2018, 7, 101-111, https://doi.org/10.7598/cst2018.1430. 
5. Fouda, A.S.; Abdel Haleem, E. Berry Leaves Extract as Green Effective Corrosion Inhibitor for $\mathrm{Cu}$ in $\mathrm{Nitric}$ Acid Solutions. Surface Engineering and Applied Electrochemistry 2018, 54, 498-507, https://doi.org/10.3103/S1068375518050034.

6. Fouda, A.S.; Rashwan, S.M.; Darwish, M.M.K.; Arman, N.M. Corrosion inhibition of Zn in a $0.5 \mathrm{M} \mathrm{HCl}$ solution by Ailanthus altissima extract. Portugaliae Electrochimica Acta 2018, 36, 309-323, https://doi.org/10.4152/pea.201805309.

7. Elabbasy, H.M.; Fouda, A.S. Olive leaf as green corrosion inhibitor for C-steel in Sulfamic acid solution. Green Chemistry Letters and Reviews 2019, 12, 332-342, https://doi.org/10.1080/17518253.2019.1646812.

8. Fouda, A.S.; Elabbasy, H.M. Corrosion inhibition effect of methanol extract of nerium oleander on copper in nitric acid solutions. Int. J. Electrochem. Sci. 2019, 14, 6884-6901, https://doi.org/10.20964/2019.07.31.

9. Elabbasy, H.M. Investigation of Withania Somnifera Extract as Corrosion Inhibitor for Copper in Nitric Acid Solutions. Int. J. Electrochem. Sci 2019, 14, 5355-5372, https://doi.org/10.20964/2019.06.23.

10. Bahlakeh, G.; Ramezanzadeh, B.; Dehghani, A.; Ramezanzadeh, M. Novel cost-effective and highperformance green inhibitor based on aqueous Peganum harmala seed extract for mild steel corrosion in $\mathrm{HCl}$ solution: Detailed experimental and electronic/atomic level computational explorations. J. Mol. Liq. 2019, 283, 174-195, https://doi.org/10.1016/j.molliq.2019.03.086.

11. Dehghani, A.; Bahlakeh, G.; Ramezanzadeh, B.; Ramezanzadeh, M. Detailed macro-/micro-scale exploration of the excellent active corrosion inhibition of a novel environmentally friendly green inhibitor for carbon steel in acidic environments. Journal of the Taiwan Institute of Chemical Engineers 2019, 100, 239-261, https://doi.org/10.1016/j.jtice.2019.04.002.

12. Sanaei, Z.; Ramezanzadeh, M.; Bahlakeh, G.; Ramezanzadeh, B. Use of Rosa canina fruit extract as a green corrosion inhibitor for mild steel in $1 \mathrm{M} \mathrm{HCl}$ solution: A complementary experimental, molecular dynamics and quantum mechanics investigation. Journal of Industrial and Engineering Chemistry 2019, 69, 18-31, https://doi.org/10.1016/j.jiec.2018.09.013.

13. Keramatinia, M.; Ramezanzadeh, B.; Mahdavian, M. Green production of bioactive components from herbal origins through one-pot oxidation/polymerization reactions and application as a corrosion inhibitor for mild steel in $\mathrm{HCl}$ solution. Journal of the Taiwan Institute of Chemical Engineers 2019, 105, 134-149, https://doi.org/10.1016/j.jtice.2019.10.005.

14. Asadi, N.; Ramezanzadeh, M.; Bahlakeh, G.; Ramezanzadeh, B. Utilizing Lemon Balm extract as an effective green corrosion inhibitor for mild steel in $1 \mathrm{M} \mathrm{HCl}$ solution: A detailed experimental, molecular dynamics, Monte Carlo and quantum mechanics study. Journal of the Taiwan Institute of Chemical Engineers 2019, 95, 252-272, https://doi.org/10.1016/j.jtice.2018.07.011.

15. majd, M.T.; Ramezanzadeh, M.; Bahlakeh, G.; Ramezanzadeh, B. Probing molecular adsorption/interactions and anti-corrosion performance of poppy extract in acidic environments. J. Mol. Liq. 2020, 304, 112750, https://doi.org/10.1016/j.molliq.2020.112750.

16. Dehghani, A.; Bahlakeh, G.; Ramezanzadeh, B.; Ramezanzadeh, M. Aloysia citrodora leaves extract corrosion retardation effect on mild-steel in acidic solution: Molecular/atomic scales and electrochemical explorations. J. Mol. Liq. 2020, 310, 113221, https://doi.org/10.1016/j.molliq.2020.113221.

17. Dehghani, A.; Bahlakeh, G.; Ramezanzadeh, B.; Ramezanzadeh, M. Potential role of a novel green ecofriendly inhibitor in corrosion inhibition of mild steel in $\mathrm{HCl}$ solution: Detailed macro/micro-scale experimental and computational explorations. Construction and Building Materials 2020, 245, 118464, https://doi.org/10.1016/j.conbuildmat.2020.118464.

18. Ngouné, B.; Pengou, M.; Nouteza, A.M.; Nanseu-Njiki, C.P.; Ngameni, E. Performances of Alkaloid Extract from Rauvolfia macrophylla Stapf toward Corrosion Inhibition of C38 Steel in Acidic Media. ACS Omega 2019, 4, 9081-9091, https://doi.org/10.1021/acsomega.9b01076.

19. Putilova, I.N.; Balezin, S.A.e.; Barannik, V.P. Metallic corrosion inhibitors; Pergamon Press: 1960.

20. Shehata, O.S.; Korshed, L.A.; Attia, A. Green corrosion inhibitors, past, present, and future, corrosion inhibitors, principles and recent applications. London: IntechOpen 2017, http://dx.doi.org/10.5772/intechopen.72753.

21. Rottenberg, A.; Zohary, D. The wild ancestry of the cultivated artichoke. Genet. Resour. Crop Evol. 1996, 43, 53-58, https://doi.org/10.1007/BF00126940.

22. Ladha, D.G.; Naik, D.U.; Shah, N.K. Investigation of Cumin (Cuminum Cyminum) extract as an eco-friendly green corrosion inhibitor for pure aluminium in acid medium. Journal of Materials and Environmental Science 2013, 4, 701-708, https://www.researchgate.net/publication/287707875.

23. Cesar, G. Plant Phenolics and Human Health-Biochemistry. Nutrition and Pharmacology. Wiley $2009,632$. 
24. Bruneton, J. Pharmacognosy, phytochemistry, medicinal plants; Lavoisier publishing: 1995.

25. Adzet, T.; Puigmacia, M. High-performance liquid chromatography of caffeoylquinic acid derivatives of Cynara scolymus L. leaves. J. Chromatogr. 1985, 348, 447-453, https://doi.org/10.1016/S00219673(01)92486-0.

26. ASTM G 1-90, Standard practice for preparing, cleaning, and evaluating corrosion test specimens. 1999.

27. Talati, J.D.; Desai, M.N.; Shah, N.K. Ortho-, meta-, and para-aminophenol-N-salicylidenes as corrosion inhibitors of zinc in sulfuric acid. Anti-Corrosion Methods and Materials 2005, 52, 108-117, https://doi.org/10.1108/00035590510584825.

28. Guruprasad, A.M.; Sachin, H.P.; Swetha, G.A.; Prasanna, B.M. Adsorption and inhibitive properties of seroquel drug for the corrosion of zinc in $0.1 \mathrm{M}$ hydrochloric acid solution. International Journal of Industrial Chemistry 2019, 10, 17-30, https://doi.org/10.1007/s40090-018-0168-x.

29. Abdel-Rehim, S.S.; Khaled, K.F.; Abd-Elshafi, N.S. Electrochemical frequency modulation as a new technique for monitoring corrosion inhibition of iron in acid media by new thiourea derivative. Electrochim. Acta 2006, 51, 3269-3277, https://doi.org/10.1016/j.electacta.2005.09.018.

30. Bosch, R.W.; Hubrecht, J.; Bogaerts, W.F.; Syrett, B.C. Electrochemical Frequency Modulation: A New Electrochemical Technique for Online Corrosion Monitoring. Corrosion 2001, 57, 60-70, https://doi.org/10.5006/1.3290331.

31. El-Etre, A.Y.; Abdallah, M. Natural honey as corrosion inhibitor for metals and alloys. II. C-steel in high saline water. Corros. Sci. 2000, 42, 731-738, https://doi.org/10.1016/S0010-938X(99)00106-7.

32. Kaczerewska, O.; Leiva-Garcia, R.; Akid, R.; Brycki, B.; Kowalczyk, I.; Pospieszny, T. Effectiveness of Obridged cationic gemini surfactants as corrosion inhibitors for stainless steel in $3 \mathrm{M} \mathrm{HCl}$ : Experimental and theoretical studies. J. Mol. Liq. 2018, 249, 1113-1124, https://doi.org/10.1016/j.molliq.2017.11.142.

33. Lgaz, H.; Salghi, R.; Subrahmanya Bhat, K.; Chaouiki, A.; Shubhalaxmi; Jodeh, S. Correlated experimental and theoretical study on inhibition behavior of novel quinoline derivatives for the corrosion of mild steel in hydrochloric acid solution. J. Mol. Liq. 2017, 244, 154-168, https://doi.org/10.1016/j.molliq.2017.08.121.

34. Ramesh Saliyan, V.; Adhikari, A.V. Inhibition of corrosion of mild steel in acid media by N'-benzylidene-3(quinolin-4-ylthio)propanohydrazide. Bull. Mater. Sci. 2008, 31, 699-711, https://doi.org/10.1007/s12034008-0111-4.

35. El-Aal, A.; Sliem, M.; Abdullah, A. Caprylamidopropyl Betaine as a highly efficient eco-friendly corrosion inhibitor for API X120 steel in 1 M H2SO4. Egyptian Journal of Chemistry 2020, 63, 759-776, https://doi.org/10.21608/ejchem.2019.13652.1844.

36. Abdul Rahiman, A.F.S.; Sethumanickam, S. Corrosion inhibition, adsorption and thermodynamic properties of poly(vinyl alcohol-cysteine) in molar HCl. Arabian Journal of Chemistry 2017, 10, S3358-S3366, https://doi.org/10.1016/j.arabjc.2014.01.016.

37. Döner, A.; Kardaş, G. N-Aminorhodanine as an effective corrosion inhibitor for mild steel in 0.5M H2SO4. Corros. Sci. 2011, 53, 4223-4232, https://doi.org/10.1016/j.corsci.2011.08.032.

38. Manaranche, C.; Hornberger, H. A proposal for the classification of dental alloys according to their resistance to corrosion. Dent. Mater. 2007, 23, 1428-1437, https://doi.org/10.1016/j.dental.2006.11.030.

39. Zeino, A.; Abdulazeez, I.; Khaled, M.; Jawich, M.W.; Obot, I.B. Mechanistic study of polyaspartic acid (PASP) as eco-friendly corrosion inhibitor on mild steel in $3 \% \mathrm{NaCl}$ aerated solution. J. Mol. Liq. 2018, 250, 50-62, https://doi.org/10.1016/j.molliq.2017.11.160.

40. Guo, L.; Kaya, S.; Obot, I.B.; Zheng, X.; Qiang, Y. Toward understanding the anticorrosive mechanism of some thiourea derivatives for carbon steel corrosion: A combined DFT and molecular dynamics investigation. J. Colloid Interface Sci. 2017, 506, 478-485, https://doi.org/10.1016/j.jcis.2017.07.082.

41. El-Sayed Shehata, O. Effect of acetamide derivative and its Mn-complex as corrosion inhibitor for mild steel in sulphuric acid. Egyptian Journal of Chemistry 2017, 60, 243-259, https://doi.org/10.21608/ejchem.2017.674.1014.

42. Hamani, H.; Douadi, T.; Daoud, D.; Al-Noaimi, M.; Rikkouh, R.A.; Chafaa, S. 1-(4-Nitrophenylo-imino)-1(phenylhydrazono)-propan-2-one as corrosion inhibitor for mild steel in $1 \mathrm{M} \mathrm{HCl}$ solution: Weight loss, electrochemical, thermodynamic and quantum chemical studies. J. Electroanal. Chem. 2017, 801, 425-438, https://doi.org/10.1016/j.jelechem.2017.08.031.

43. Laamari, M.R.; Benzakour, J.; Berrekhis, F.; Derja, A.; Villemin, D. Adsorption and corrosion inhibition of carbon steel in hydrochloric acid medium by hexamethylenediamine tetra(methylene phosphonic acid). Arabian Journal of Chemistry 2016, 9, S245-S251, https://doi.org/10.1016/j.arabjc.2011.03.018. 
44. Chauhan, D.S.; Ansari, K.R.; Sorour, A.A.; Quraishi, M.A.; Lgaz, H.; Salghi, R. Thiosemicarbazide and thiocarbohydrazide functionalized chitosan as ecofriendly corrosion inhibitors for carbon steel in hydrochloric acid solution. Int. J. Biol. Macromol. 2018, 107, 1747-1757, https://doi.org/10.1016/j.ijbiomac.2017.10.050.

45. Salhi, A.; Tighadouini, S.; El-Massaoudi, M.; Elbelghiti, M.; Bouyanzer, A.; Radi, S.; El Barkany, S.; Bentiss, F.; Zarrouk, A. Keto-enol heterocycles as new compounds of corrosion inhibitors for carbon steel in $1 \mathrm{M} \mathrm{HCl}$ : Weight loss, electrochemical and quantum chemical investigation. J. Mol. Liq. 2017, 248, 340-349, https://doi.org/10.1016/j.molliq.2017.10.040.

46. Mohan, R.; Joseph, A. Corrosion protection of mild steel in hydrochloric acid up to $313 \mathrm{~K}$ using propyl benzimidazole: Electroanalytical, adsorption and quantum chemical studies. Egyptian Journal of Petroleum 2018, 27, 11-20, https://doi.org/10.1016/j.ejpe.2016.12.003.

47. Benabdellah, M.; Tounsi, A.; Khaled, K.F.; Hammouti, B. Thermodynamic, chemical and electrochemical investigations of 2-mercapto benzimidazole as corrosion inhibitor for mild steel in hydrochloric acid solutions. Arabian Journal of Chemistry 2011, 4, 17-24, https://doi.org/10.1016/j.arabjc.2010.06.010.

48. Reis, F.M.; de Melo, H.G.; Costa, I. EIS investigation on Al 5052 alloy surface preparation for selfassembling monolayer. Electrochim. Acta $\quad$ 2006, $\quad$ 1780-1788, https://doi.org/10.1016/j.electacta.2005.02.118.

49. Solmaz, R.; Kardaş, G.; Çulha, M.; Yazıc1, B.; Erbil, M. Investigation of adsorption and inhibitive effect of 2-mercaptothiazoline on corrosion of mild steel in hydrochloric acid media. Electrochim. Acta 2008, 53, 5941-5952, https://doi.org/10.1016/j.electacta.2008.03.055.

50. Tao, Z. H.; Zhang, S. T.; Li, W. H.; Hou, B. R. Corrosion inhibition of mild steel in acidic solution by some oxo-triazole derivatives. Corros. Sci. 2009, 51, 2588-2595, https://doi.org/10.1016/j.corsci.2009.06.042.

51. Yousefi, A.; Javadian, S.; Dalir, N.; Kakemam, J.; Akbari, J. Imidazolium-based ionic liquids as modulators of corrosion inhibition of SDS on mild steel in hydrochloric acid solutions: experimental and theoretical studies. RSC Advances 2015, 5, 11697-11713, https://doi.org/10.1039/C4RA10995C.

52. Volpi, E.; Foiadelli, C.; Trasatti, S.; Koleva, D.A. Development of Smart Corrosion Inhibitors for Reinforced Concrete Structures Exposed to a Microbial Environment. Ind. Eng. Chem. Res. 2017, 56, 5778-5794, https://doi.org/10.1021/acs.iecr.7b00127.

53. Zheng, X.; Gong, M.; Li, Q.; Guo, L. Corrosion inhibition of mild steel in sulfuric acid solution by loquat (Eriobotrya japonica Lindl.) leaves extract. Sci. Rep. 2018, 8, 9140, https://doi.org/10.1038/s41598-01827257-9.

54. Shalabi, K.; Abdallah, Y.; Hassan, H.; Fouda, A. Effects of Arctostaphylos uva-ursi Extract as Green Corrosion Inhibitor for Cu10Ni Alloy in $1 \mathrm{M}$ HNO3. International journal of electrochemical science 2014, 9, 5073, https://www.researchgate.net/publication/263274403.

55. Fouda, A.; Shalabi, K.; Elewady, G.; Emrayed, H. Chalcone Derivatives as Corrosion Inhibitors for Carbon Steel in $1 \mathrm{M} \mathrm{HCl} \mathrm{Solutions.} \mathrm{International} \mathrm{journal} \mathrm{of} \mathrm{electrochemical} \mathrm{science} \mathrm{2014,} \mathrm{9,} \mathrm{7038-7058,}$ https://www.researchgate.net/publication/266262341.

56. Rajendran, S.; Thangavelu, C.; Annamalai, G. Inhibition of corrosion of aluminium in alkaline medium by succinic acid in conjunction with zinc sulphate and diethylene triamine penta (Methylene phosphonic acid). J. Chem. Pharm. Res. 2012, 4, 4836-4844, https://www.researchgate.net/publication/286571211.

57. Mu, G.; Li, X.; Liu, G. Synergistic inhibition between tween 60 and $\mathrm{NaCl}$ on the corrosion of cold rolled steel in 0.5M sulfuric acid. Corros. Sci. 2005, 47, 1932-1952, https://doi.org/10.1016/j.corsci.2004.09.020.

58. Wang, B.; Du, M.; Zhang, J.; Gao, C.J. Electrochemical and surface analysis studies on corrosion inhibition of Q235 steel by imidazoline derivative against CO2 corrosion. Corros. Sci. 2011, 53, 353-361, https://doi.org/10.1016/j.corsci.2010.09.042.

59. Chugh, B.; Singh, A.K.; Thakur, S.; Pani, B.; Lgaz, H.; Chung, I.-M.; Jha, R.; Ebenso, E.E. Comparative Investigation of Corrosion-Mitigating Behavior of Thiadiazole-Derived Bis-Schiff Bases for Mild Steel in Acid Medium: Experimental, Theoretical, and Surface Study. ACS Omega 2020, 5, 13503-13520, https://doi.org/10.1021/acsomega.9b04274.

60. Obi-Egbedi, N.O; Obot, I.B. Xanthione: A new and effective corrosion inhibitor for mild steel in sulphuric acid solution. Arabian Journal of Chemistry 2013, 6, 211-223, https://doi.org/10.1016/j.arabjc.2010.10.004.

61. Ituen, E.; Akaranta, O.; James, A. Green anticorrosive oilfield chemicals from 5-hydroxytryptophan and synergistic additives for X80 steel surface protection in acidic well treatment fluids. J. Mol. Liq. 2016, 224, 408-419, https://doi.org/10.1016/j.molliq.2016.10.024. 
62. Goel, R.; Siddiqi, W.A.; Ahmed, B.; Khan, M.S.; Chaubey, V.M. Synthesis characterization and corrosion inhibition efficiency of N-C2 \{(2E)-2-[4-(dimethylamino) benzylidene] hydrazinyl $\}$ 2-oxo ethyl benzamide on mild steel. Desalination 2010, 263, 45-57, https://doi.org/10.1016/j.desal.2010.06.033.

63. Aytaç, A.; Bilgiç, S.; Gece, G.; Ancın, N.; Öztaş, S.G. Experimental and theoretical study of the inhibition effects of some Schiff bases as corrosion inhibitors of aluminium in $\mathrm{HCl}$. Mater. Corros. 2012, 63, 729-734, https://doi.org/10.1002/maco.201106241.

64. Allam, N.K. Thermodynamic and quantum chemistry characterization of the adsorption of triazole derivatives during Muntz corrosion in acidic and neutral solutions. Appl. Surf. Sci. 2007, 253, 4570-4577, https://doi.org/10.1016/j.apsusc.2006.10.008.

65. Santos, A.d.M.; Almeida, T.F.d.; Cotting, F.; Aoki, I.V.; Melo, H.G.d.; Capelossi, V.R. Evaluation of castor bark powder as a corrosion inhibitor for carbon steel in acidic media. Materials Research 2017, 20, 492-505, https://doi.org/10.1590/1980-/5373-MR-2016-0963.

66. Idouhli, R.; N'Ait Ousidi, A.; Koumya, Y.; Abouelfida, A.; Benyaich, A.; Auhmani, A.; Ait Itto, M.Y. Electrochemical Studies of Monoterpenic Thiosemicarbazones as Corrosion Inhibitor for Steel in $1 \mathrm{M} \mathrm{HCl}$. International Journal of Corrosion 2018, 2018, 9212705, https://doi.org/10.1155/2018/9212705.

67. Obot, I.B.; Obi-Egbedi, N.O. Indeno-1-one [2,3-b]quinoxaline as an effective inhibitor for the corrosion of mild steel in $0.5 \mathrm{M} \mathrm{H} 2 \mathrm{SO} 4$ solution. Mater. Chem. Phys. 2010, 122, 325-328, https://doi.org/10.1016/j.matchemphys.2010.03.037.

68. Mert, B.D.; Erman Mert, M.; Kardaş, G.; Yazıcı, B. Experimental and theoretical investigation of 3-amino1,2,4-triazole-5-thiol as a corrosion inhibitor for carbon steel in $\mathrm{HCl}$ medium. Corros. Sci. 2011, 53, 42654272, https://doi.org/10.1016/j.corsci.2011.08.038.

69. Roque, J.M.; Pandiyan, T.; Cruz, J.; García-Ochoa, E. DFT and electrochemical studies of tris(benzimidazole-2-ylmethyl)amine as an efficient corrosion inhibitor for carbon steel surface. Corros. Sci. 2008, 50, 614-624, https://doi.org/10.1016/j.corsci.2007.11.012.

70. Fouda, A.E.-A.S.; Farahat, M.M.; Abdallah, M. Cephalosporin antibiotics as new corrosion inhibitors for nickel in HCl solution. Res. Chem. Intermed. 2014, 40, 1249-1266, https://doi.org/10.1007/s11164-013-10360 .

71. Abd, E.-A.F.S.; Ali, A.H. Egy-dronate drug as promising corrosion inhibitor of C-steel in aqueous medium. Zaštita materijala 2018, 59, 126-140, https://doi.org/10.5937/ZasMat1801128F. 